\title{
Algılanan Ebeveyn İzlemesi, Siber Zorbalık ve Yaşam Doyumu Arasındaki İlişkiler Ergenin Cinsiyetine Göre Farklılaşıyor mu?
}

\section{Does the Associations among Perceived Parental Monitoring, Cyberbullying, and Life Satisfaction of Adolescents Differ in Boys and Girls?}

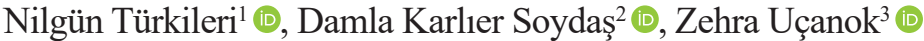

'Dr., Nevşehir Hacı Bektaş Veli Üniversitesi, Fen Edebiyat Fakültesi, Psikoloji Bölümü, Nevşehir, Türkiye

${ }^{2}$ Uzm. Psk., Tarsus 1 Nolu T Tipi Kapalı Ceza İnfaz Kurumu, Mersin, Türkiye

${ }_{3}^{3}$ Prof. Dr., Hacettepe Ǘniversitesi, Edebiyat Fakültesi, Psikoloji Bölümü, Ankara, Türkiye

ORCID: N.T. 0000-0002-0033-2748;

D.K.S. 0000-0002-1322-6864;

Z.U. 0000-0003-3953-300X

\section{Sorumlu yazar/Corresponding author:} Nilgün Türkileri,

Nilgun Turkileri,
Nevsehir Hacı Bektas Veli Üniversitesi, Fen Edebsiyat Fakültesi, Psikoloji Bölümü, 2000 Edebiyat Fakültesi, Psikoloji Bölümü, 2000 Evler Mah. Zübeyd

E-posta/E-mail: nilturkileri@gmail.com

Yazar notu: Bu çalışma TUBITAK Sosyal ve Beseri Bilimler Araştırma Projeleri (Proje No:108K424) kapsamında desteklenmiştir.

Başvuru/Submitted: 29.12.2020 Revizyon Talebi/Revision Requested: 28.02.2021

Son Revizyon/Last Revision Received: 26.04.2021

Kabul/Accepted: 17.05 .2021

Online Yayın/Published Online: 16.12.2021

Citation/Atıf: Turkileri, N., Karlier Soydas, D. ve Ucanok, Z. (2021). Algılanan ebeveyn izlemesi, siber zorbalık ve yaşam doyumu arasındaki ilișkiler ergenin cinsiyetine göre farklılasıyor mu? Psikoloji Calıșmaları - Studies farklilaşıyor mu? Psikoloji çalıș https://doi.org/10.26650/SP2020-849445
ÖZ

$\mathrm{Bu}$ araştırmanın temel amacı ilk ve orta ergenlik döneminde algılanan ebeveyn izlemesi ile yaşam doyumu arasındaki ilişkiyi ve bu ilişkide siber zorbalığa maruz kalma ve siber zorbalık uygulamanın aracı rolünü ergenin cinsiyetine göre incelemektir. Algılanan ebeveyn izlemesi, ergenin okul dışı ve çevrimiçi aktiviteleri hakkında anne babasının bilgi sahibi olmasını ifade etmektedir. Yaşam doyumu ise benlik, okul, arkadaş, aile ve yaşanılan çevreden duyulan memnuniyeti kapsamaktadır. Çalışmanın örneklemini toplam 1395 (\%52.5 kız ve $\% 47.5$ erkek) ortaokul ve lise öğrencisi (Ort. yas $=14.87, S=2.04$ ) oluşturmuştur. Ergenlere Ebeveyn İzlemesi Ölçeği, Öğrenciler için Çok Boyutlu Yaşam Doyumu Ölçeği ve Sanal/Siber Zorbalık Ölçeği sınıf ortamında grup halinde uygulanmıştır. Bulgular, beklentiyle uyumlu biçimde, ebeveynlerinden daha fazla izleme algılayan ergenlerin daha yüksek düzeyde yaşam doyumu rapor ettiğini göstermiştir. Benzer şekilde, ebeveyn izlemesini daha yüksek algılayan ergenlerin daha düşük düzeyde siber zorbalık rapor ettikleri gözlenmiştir. Yapısal Eşitlik Modeli analiz sonuçlarına göre siber zorbalığa maruz kalmanın, hem kız hem de erkek ergenler için, ebeveyn izlemesi ile ergenin yaşam doyumu arasındaki pozitif yöndeki ilişkide kısmi aracı rol oynadığı görülmektedir. Öte yandan, sadece erkek ergenlerde ebeveyn izlemesi ile ergenin yaşam doyumu arasındaki ilişkide siber zorbalık uygulama kısmi aracı rol oynamaktadır. Ancak kızlarda siber zorbalık uygulama ile yaşam doyumu arasındaki ilişkinin anlamsız olmasından dolayı aracı etki test edilmemiştir. Elde edilen bu yöndeki ilişkiler, ergenin cinsiyetinin önemli bir faktör olarak ele alınması gerektiğini ortaya koymaktadır. Araştırmadan elde edilen bulgular genel olarak değerlendirildiğinde ise ergenlerde riskli davranışları azaltmada ve onların sağlıklı bireyler olarak yetişmelerinde anne babaların aktif izleme uygulamalarının rolünü vurgulayan görüşleri desteklemektedir.

Anahtar Kelimeler: İlk ve orta ergenlik, ebeveynlik uygulamaları, ebeveyn izlemesi, sanal/siber zorbalık, bireysel iyilik hali 


\section{ABSTRACT}

The present study mainly aims to examine the relationship between perceived parental monitoring and life satisfaction during early and middle adolescence (aged between 12-18) and the mediating role of exposure to cyberbullying and cybervictimization in this relationship according to gender. Perceived parental monitoring refers to the knowledge of parents about the out-of-school and online activities of adolescents, whereas life satisfaction pertains to the level of satisfaction of students with their self, school, friends, family, and environment. The sample consisted of 1,395 (female: 52.5\%; male: $47.5 \%)$ secondary school and high school students $(M=14.87, S D=2.04)$. The participants completed a package of four self-report questionnaires, namely, a Demographic Information Form, the Parental Monitoring Scale, the Multidimensional Students' Life Satisfaction Scale, and the Cyberbullying Scale in the classroom setting. As hypothesized, the results demonstrated that adolescents with perceived high levels of parental monitoring reported high levels of life satisfaction and low levels of cyberbullying. The results of structural equation modeling indicated that cybervictimization plays a partially mediating role in the positive relationship between parental monitoring and adolescent life satisfaction for both genders. However, cyberbullying partially mediates the relationship between parental monitoring and adolescent life satisfaction only in male adolescents. However, this mediating effect was not tested for the female participants due to the non-significance of the relationship between cyberbullying and life satisfaction. The relationship in this direction reveals that gender should be considered an important factor. In summary, these findings suggest that perceived parental monitoring plays a protective role in the general well-being of adolescents by reducing risky online behaviors, such as bullying in cyberspace.

Keywords: Early and middle adolescence, parental strategies, parental monitoring, cyberbullying, cybervictimization, well-being

\section{EXTENDED ABSTRACT}

Although adolescents spend progressively more time with peers and less time with parents (Larson, Richards, Moneta, Holmbeck, \& Duckett, 1996), parental monitoring remains important during adolescence. Despite the numerous advantages of information and communication technologies, adolescents may experience certain risks associated with bullying on the Internet or using other digital tools. Therefore, parents are challenged to modify their monitoring strategies and to exceed conventional methods for protecting children from online risks. Research suggests that parental roles in online activities, such as active supervision and monitoring, may be considered protective factors, whereas restrictive control (e.g., imposing rules) may result in further risky behaviors associated with cybervictimization and cyberbullying (Baldry, Sorrentino, \& Farrington, 2019). Although cyberbullying has been linked to many negative consequences, such as internalization and externalization problems (e.g., Mitchell, Wolak, \& Finkelhor, 2008), studies that investigated the relationship between cyberbullying and adolescent life satisfaction are few (Moore, Huebner, \& Hills, 2012; Navarro, Ruiz-Oliva, Larrañaga, \& Yubero, 2015).

To fill this research gap, the present study aimed to examine the mediating role of cyberbullying and cybervictimization on the relationship between parental monitoring and life satisfaction during early and middle adolescence. The study predicted that perceived parental monitoring would be negatively related to cyberbullying/cybervictimization 
and positively associated with life satisfaction. Moreover, the study hypothesized that cyberbullying/cybervictimization would mediate the relationship between parental monitoring and life satisfaction.

\section{Method}

The sample consisted of 1,395 secondary and high school students (female: $52.5 \%$; male: $47.5 \%$ ) with a mean age of 14.87 years. The schools were selected from six mediumand large-sized cities in Turkey. The adolescents completed a package of four self-report questionnaires, namely, a Demographic Information Form, the Parental Monitoring Scale (Kerr \& Stattin, 2000; Sayıl et al., 2012); the Cyberbullying Inventory (Karlıer-Soydaş \& Uçanok, 2014), and the Multidimensional Students' Life Satisfaction Scale (Huebner, 1994; Irmak \& Kuruüzüm, 2008).

\section{Results}

The results revealed that parental monitoring negatively predicted cyberbullying but positively predicted life satisfaction for both genders. However, cyberbullying negatively predicted life satisfaction only for the male participants. Moreover, the relationship between cyberbullying and life satisfaction was non-significant for the female participants, which did not require testing for the mediating role of cyberbullying. For the male participants, adding cyberbullying into the model significantly decreased the relationship between perceived parental monitoring and life satisfaction from .36 to $.33\left(\mathrm{z}_{\text {male }}=2.13, p<.01\right)$. Thus, cyberbullying mediated the relationship between perceived parental monitoring and life satisfaction.

For the mediating role of victimization, parental monitoring negatively predicted cybervictimization but positively predicted life satisfaction, whereas cybervictimization negatively predicted life satisfaction for both genders. Furthermore, adding cybervictimization into the model significantly decreased the relationship between perceived parental monitoring and life satisfaction from .35 to .32 for the females and from .36 to .34 for the males $\left(z_{\text {female }}=2.38, p<.01 ; z_{\text {male }}=2.43, p<.01\right)$. Thus, cybervictimization mediated the relationship between perceived parental monitoring and life satisfaction.

\section{Discussion}

Consistent with previous studies (e.g., Baldry et al., 2019), the current results indicated that perceived parental knowledge as an active monitoring strategy was related to less involvement in bullying via digital tools. Thus, research suggested that active and evaluative 
monitoring, such as discussing online risks with children, were considered protective factors, whereas restrictive control, such as limiting Internet use, may be associated with high levels of bullying (e.g., Laird, Zeringue, \& Lambert, 2018). Therefore, this study conceptualized parental monitoring as perceived parental knowledge about the online and offline activities, whereabouts, and companions of adolescents. Furthermore, research suggest that cyberbullies tend to morally disengage (Kowalski, Giumetti, Schroeder, \& Lattanner, 2014). Thus, this study argued that perceived parental knowledge of online activities may help adolescents in adjusting their moral reasoning toward more prosocial acts in cyberspace. Moreover, in line with a few studies (e.g., Suldo \& Huebner, 2004), the current findings suggested that parental monitoring is positively related to life satisfaction. Thus, these results supported the concept that parental knowledge, as a means of active monitoring, plays a pivotal role in protecting children from online risks and supporting their general well-being.

Finally, the results supported the hypothesis and suggested that cyberbullying/ cybervictimization mediated the relationship between parental monitoring and life satisfaction. In other words, parental knowledge of the online communication of adolescents plays an important role in the well-being of adolescents through protection from involvement in cyberbullying/cybervictimization. To date, studies that focused on the relationship between cyberbullying and the well-being of adolescents are very few (e.g., Moore et al., 2012). In fact, psychologists throughout history have focused more on the negative aspects of people's lives and less on positive psychological well-being (Diener, Suh, Lucas, \& Smith, 1999). Therefore, these results may have the potential to expand the growing literature on positive psychological effects related to adolescents.

The findings provide insights for understanding bullying and victimization in cyberspace. However, the generalizability of these results is subject to certain limitations, such as reliance on self-report measures and the cross-sectional nature of the design. Despite these limitations, the results support the view that parents should be aware of the benefits and risks of the digital age and actively use new strategies for supporting the health and wellbeing of their children. 
Çocukluktan ergenliğe geçiş bir dizi gelişimsel değişikliği ve dönüşümü beraberinde getirmekte; ergenler yaş ilerledikçe aileleriyle daha az, akranlarıyla daha fazla vakit geçirmeye başlamaktadır (Larson, Richards, Moneta, Holmbeck ve Duckett, 1996). Bu doğrultuda akran ilişkileri oluşturma ve var olan ilişsileri sürdürme bahsedilen dönemin temel gelişimsel görevlerinden biridir. Bununla birlikte, ergenlik dönemi boyunca, ergenlerin anne babaları veya diğer bakım verenleri ile ilişkileri onların sağlıklı bir birey olarak yetişmesi ve psikolojik işlevsellikleri açısından önemini korumaktadır (Steinberg ve Silk, 2002). Günümüzde bilgi ve iletişim teknolojilerinin yaşamın vazgeçilmez bir parçası haline gelmesi, ergen sağlığı açısından birer tehdit unsuru olan internet tacizi ya da siber/sanal zorbalık gibi pek çok sorunu da gündeme getirmektedir. Siber zorbalık, bir kişi ya da grup tarafından kendini kolaylıkla savunamayan bir kişiye yönelik olarak elektronik temelli iletişim araçları yoluyla uygulanan saldırgan davranışlar olarak tanımlanmaktadır (Smith ve ark., 2008, s. 376). Dolayısıyla internet tacizi, siber zorbalık ya da sosyal medya bağımlığı gibi bu güncel sorunlar, ebeveynlik davranış ve stratejilerini de geleneksel uygulamaların dışına taşımayı gerektirmektedir.

Ebeveynlik uygulamalarının doğrudan sanal ortamdaki zorbalıkla ilişkisine yönelik bilgi birikiminin görece daha sınırlı olduğu ve bu uygulamaların ergenin psikolojik uyumu üzerindeki etkilerini ele alan araştırmaların önemli bir bölümünün de depresyon, kaygı gibi içe yönelim ile öfke, saldırganlık gibi dışa yönelim problemlerine odakland1ğ1 görülmektedir (Kowalski, Giumetti, Schroede ve Lattanner, 2014). Dolayısıyla, yaşadıkları çok yönlü değişimlerle baş etme, kimlik arama ve özerklik kazanma, akran ilişkileri oluşturma ve sürdürme çabası içinde olan ergenlerin davranış ve hareketlerinin uygun ve yeterli şekilde izlenmesinin, sanal ortamda deneyimleyebilecekleri riskli davranışları azaltarak psikolojik iyiliklerine katkı sağlayabileceği düşünülmektedir. Bu noktadan hareketle, araştırmanın temel amacı ilk ve orta ergenliği temsil eden gelişimsel dönemde algılanan ebeveynlik uygulaması (izleme) ile yaşam doyumu arasındaki ilişkiyi ve bu ilişkide siber zorbalığa dahil olmanın aracı rolünü ergenin cinsiyetine göre incelemektir. Bu amaca yönelik olarak mevcut çalışmada ergenlerin deneyimlediği zorbalık hem bu tür davranışları uygulama (zorba) hem de bu davranışlara maruz kalma (kurban) boyutlarıyla ele alınarak ilgili alan yazının genişletilmesi hedeflenmiştir. Alan yazında olumlu kontrol uygulamalarından biri olarak değerlendirilen ve genellikle ergenin ev dışındaki aktiviteleri hakkında anne babanın bilgi sahibi olması olarak tanımlanan (Kerr ve Stattin, 2000) ebeveyn izlemesi bu çalışmada 'çocuğunun internet 
ortamındaki faaliyetleri hakkında bilgi sahibi olmasını’ da kapsayacak biçimde ele alınmiştır.

\section{Geleneksel Akran Zorbalığı ve Ebeveynlik Uygulamaları}

Sanal ortamda deneyimlenen saldırganlığın ve zorbaca davranışların incelenmesinde büyük ölçüde okul zorbalığı ya da geleneksel akran zorbalığı alan yazınından faydalanılmaktadır (Olweus, 2013). Araştırmacılar neden bazı çocukların ya da ergenlerin daha sıklıkla zorbalığa dahil olduğunu belirlemeye çalışırken, Bronfenbrenner'in (1999) insan gelişimini, bireyin kendi özellikleri ile çevresi arasındaki ilişkilerin bir fonksiyonu olarak ele aldığı Biyoekolojik Modeli’nden yararlanmaktadır. Buna göre, insan gelişimi gibi karmaşık bir fenomen mikro düzeyden (yaş, cinsiyet gibi bireysel farklılıklar) makro düzeye doğru (kültürel ve evrensel değerler gibi) ancak sistematik bölümlere ayrilarak incelenebilir. Bu mikrosistemlerden birisi de aile dinamikleridir ve bu bağlamda, aile özelliklerinin siber zorbalık davranışları üzerindeki rolünü ele alan araştırmalar ebeveynlik stilleri, ebeveynlik uygulamaları, ebeveyn-ergen ilişki niteliği ve bağlanma güvenliği gibi çeşitli alanlara odaklanmaktadır (Hong ve Espelage, 2012). Örneğin, zorbalığa dahil olan çocukların ailelerinin daha tutarsız ve sert disiplin uyguladıkları, daha çok otoriter ebeveynlik stiline sahip oldukları ve saldırgan davranışları daha çok, olumlu sosyal etkileşimleri ise daha az pekiştirdikleri görülmektedir (Lereya, Samara ve Wolke, 2013). Diğer yandan, aşırı koruyucu ebeveynlik tutumları (Finnegan, Hodges ve Perry, 1998), sıcak ve destekleyici olmayan bir aile ortamı ve çocuğa kötü muameleyi içeren ebeveyn davranışları (Bolger ve Patterson, 2001) ile zorbalığa maruz kalma arasında pozitif yönde ilişkiler ortaya konmuştur.

\section{Siber Zorbalık ve Ebeveyn İzlemesi}

Ebeveynlik uygulamaları, anne babanın inançları, değerleri ve hedefleri doğrultusunda çocuklarını sosyalleştirmede kullandıkları davranışlar olarak tanımlanmaktadır (Darling ve Steinberg, 1993). Bu uygulamalar ebeveyn desteği ve ebeveyn kontrolü olmak üzere iki boyutta ele alınmaktadır (Barber, Stolz ve Olsen, 2005). Ebeveyn desteği, anne ve babanın çocuğunun duygu ve düşüncelerine değer verdiğini göstermesi ve ebeveyn-çocuk arasındaki ilişkinin kalitesi olarak ifade edilmektedir (Galambos, Barker ve Almeida, 2003). Ebeveyn kontrolü ise sevgiyi esirgeme ya da koşullu sunma, utandırma ve suçluluk yaratma gibi psikolojik kontrol ya da çocuğun davranışlarını aile içi kurallar ve sosyal normlar çerçevesinde düzene sokma ve denetim altına alma girişimini ifade eden davranışsal kontrol olarak kavramsallaştırılmaktadır (Barber, 1996). Bu kapsamda 
ele alınan ebeveynlik uygulamalarından birisi de davranışsal kontrolün bir boyutu olan ebeveyn izlemesidir. İzleme, ergenin kendisini ebeveyninden ayrı bir birey olarak hissedebilmesi için gereken psikolojik özerkliğini kısıtlamadan, ergenin nerede ve kimlerle olduğunu, neler yaptığını ve akranlarıyla ilişskileri hakkında bilgi sahibi olma girişimini ifade etmektedir (Stattin ve Kerr, 2000). Araştırmalar ebeveyn izlemesinin, yaşam doyumu da dahil olmak üzere (Piko ve Hamvai, 2010) ergenin uyumu üzerinde olumlu etkisi olduğuna işaret etmektedir (Hoskins, 2014).

Günümüzde ergenler internete erişimin olduğu herhangi bir yerde, evlerinden hatta odalarından bile ayrılmadan akranlarıyla olan iletişimlerini sürdürebilmekte; dolayısıyla anne babalar da çocuklarının çevrimiçi faaliyetlerini kontrol edebilmek için ekstra çaba sarf etme gereği duyabilmektedirler. Türkiye İstatistik Kurumu'nun (TÜİK, 2019) verilerine göre 2019 yılı hane halkı internet erişimi yaklaşık \%88'e ulaşmıştır. Ayrıca internetin eğitim amaçlı kullanımı ülkemizde ve dünyada meydana gelen teknolojik gelişmelere paralel biçimde dramatik şekilde artmaktadır. Çocuklar ve ergenlerin bilgi ve iletişim teknolojilerini tek başlarına ve denetimsiz olarak kullanmaları internet ortamında meydana gelebilecek antisosyal davranışlar açısından bir risk faktörü olabilmektedir. Üstelik bazı anne babalar okul ortamı veya diğer sosyalleşme ortamlarına kıyasla sanal ortamı daha az tehlikeli bulmakta ve internette yasaklı sitelere ulaşım gibi tehlikeleri küçümseyebilmektedir (Livingstone ve Bober, 2004). Ayrıca ilk 'dijital yerliler' olarak adlandırılan ve teknolojinin içine doğan günümüz çocukları elektronik iletişim araçlarını kullanmada ebeveynlerinden daha üstün becerilere sahip olmaktadır (Palfrey ve Gasser, 2008). Bu durum, ebeveynlerin davranış ve uygulamalarını güncellemelerini; geleneksel olarak uyguladıkları strateji ve yöntemlerin dışında yeni izleme yöntemleri denemelerini kaçınılmaz hale getirmektedir.

Tüm bu bulgular 1şığında, ergenlerin çevrimiçi davranışlarını kontrol etme ve izleme davranışları, aktif izleme (birlikte internete girme gibi), değerlendirme (internet güvenliği hakkında karşılıklı konuşup anlaşma gibi) ya da kısıtlayıcı uygulamalar (interneti s1nırlama, kuralları empoze etme gibi) olarak ele alınmaktadır (Baldry, Sorrentino ve Farrington, 2019; Elsaesser, Russell, Ohannessian ve Patton, 2017; Kowalski ve ark., 2014). Araştırmacılar, ergen hakkında bilgi sahibi olan ebeveynlerin çocuklarını olumsuz davranışlara karşı koruyabileceklerini öne sürmekte ve yüksek düzeyde ebeveyn izlemesinin ergenlerin daha az problem davranışlarda bulunmalarıyla ilişkili olduğu ifade edilmektedir (Jacobson ve Crockett, 2000; Kerr ve Stattin, 2000). Örneğin, internet gü- 
venliği ve internet aktiviteleri konusunda karşılıklı anlaşarak kurallar konulması gibi aktif izleme ve değerlendirme uygulamalarının sanal ortamda zorbalığa maruz kalmaya karşı koruyucu bir rolü olduğu gösterilmiştir (Floros, Siomos, Fisoun, Dafouli ve Geroukalis, 2013; Navarro, Serna, Martinez ve Ruiz-Oliva, 2013). Bu bağlamda yürütülen kapsamlı bir gözden geçirme çalışmasında ebeveyn rehberliği ve izlemenin siber zorbalık davranışları sergilemede koruyucu bir faktör olduğu sonucuna ulaşılmıştır. Ancak aynı araştırmada aşırı koruyucu ebeveynlik uygulamalarının zorbalığa maruz kalmada bir risk oluşturduğuna dair elde edilen bulguların tutarlı olmadığı vurgulanmıştır (Nocentini, Fiorentine, Di Paola ve Menesini, 2018). Dahası, ergenin internet aktivitelerini kısıtlayıcı türden ebeveynlik uygulamalarının ergenin riskli davranışlarını arttırdığını gösteren çalışmalar da mevcuttur (Álvarez-García, Pérez, González ve Pérez, 2015). Örneğin, Meter ve Bauman (2018), okul çağı çocukları ve ilk ergenlik dönemini kapsayan çalışmalarında, algılanan yüksek düzeyde ebeveyn izlemesi ile sanal ortamda zorbalığa dahil olma arasında pozitif yönde bir ilişki olduğunu rapor etmiştir. Araştırmacılar, beklentinin tersi yönünde elde edilen bulguları çalışmanın enlemesine kesitsel doğasına işaret ederek açıklamışlardır. Buna göre, daha sıklıkla zorbaca davranışlar bildiren çocukların ve ergenlerin anne babalarının internet ortamındaki faaliyetler konusunda daha duyarlı hale gelebileceğini; dolayısıyla bu durumun da çocuklarda daha yoğun ve sıkı bir biçimde takip edildikleri yönünde bir alg1 oluşturabileceğini öne sürmüşlerdir. Benzer şekilde, internet ortamında ebeveynleri tarafından uygulanan kısıtlayıcı türde gözetim ve denetimin ergenlerin riskli çevrimiçi aktivitelerini artırdığına ilişkin bulgular elde edilmiştir (Sasson ve Mesch, 2014). Bu çalışmalar birlikte değerlendirildiğinde, ebeveynin ergenin internet faaliyetlerine dair bilgi sahibi olmasını içeren aktif izleme uygulamalarının ergenin problem davranışlarının azaltılmasında olumlu bir etkiye sahip olduğu; ancak kısıtlayıcı türden izleme uygulamalarının etkililiğine yönelik ise çelişkili bulgular elde edildiği öne sürülmektedir (Laird, Zeringue ve Lambert, 2018).

\section{Ebeveyn İzlemesi ve Siber Zorbalık Arasındaki İlişkide Ergenin Cinsiyetinin Rolü}

Ebeveyn izlemesinin siber zorbalığa dahil olmadaki rolü incelenirken ergenin cinsiyet ve etnik köken gibi bazı bireysel özellikleri de önemli bir faktör olarak ortaya çıkmaktadır. Örneğin, Wright (2017) kısıtlayıcı uygulamaların erkeklerden daha çok kız ergenler için siber zorbalığa maruz kalmada koruyucu bir etkisi olduğunu göstermiştir. Araştırmacı bu durumun ebeveynlerin kız ergenlerin daha fazla risk altında olduğunu düşündüğü için onlara internet aktivitelerini daha fazla sınırlandırıcı uygulamalarda bu- 
lunmalarından kaynaklanabileceğini önermiştir. Öte yandan, 13-20 yaşları arasında İtalyan gençlerle yapılan bir başka çalışmada ise siber zorbalığa hedef olduğunu bildiren k1z ergenler daha yüksek düzeyde ebeveyn denetlemesi rapor etmiştir. Elde edilen bu yöndeki bulguyu araştırmacılar, yine anne babaların daha fazla endişe duyduğu için kızlarının faaliyetlerini daha fazla denetleme ihtiyacı duydukları şeklinde açıklamışlardır. Sözü edilen çalışmanın bulguları erkek ergenler için farklılaşmış ve sanal ortamda zorbaca davranışlar sergilemedeki risk faktörleri olarak erkek olmak, yaşça daha büyük olmak, internette daha fazla zaman geçirmek ve ebeveynin internet aktivitelerini kontrol etmesi olarak belirlenmiştir (Baldry ve ark., 2019). Amerika'da yapılan boylamsal bir çalışmada da Afrikalı Amerikalı ve beyaz Amerikalı ergenlerin rapor ettiği ebeveyn izlemesinin (aktiviteleri ve arkadaşları hakkındaki ebeveyn farkındalığı) kız ve erkek ergenlerde farklı örüntüler gösterdiği bulunmuştur (Low ve Espelage, 2013). Buna göre, beyaz Amerikalı kızlarda ebeveyn izlemesi sanal ortamda zorbalık uygulamaya olumsuz yönde etki ederken, ergenin alkol ve madde kullanımı gibi bireysel faktörler bu ilişkiye aracılık etmektedir. Öte yandan, erkek ergenler için ise hem aile içi şiddet hem de ebeveyn izlemesi siber zorbalığa dahil olmada risk faktörleri olarak gösterilmiş ve bu ilişkiye beyaz Amerikalı erkeklerde düşmanlık gibi bireysel özelliklerin ve Afrikalı Amerikalı erkeklerde depresif semptomların aracılık ettiği gözlenmiştir.

\section{Siber Zorbalık ve Yaşam Doyumu}

Sanal ortamda gerçekleşen zorbalık doğası gereği çoğu zaman doğrudan ve yüz yüze bir iletişimi içermemesine rağmen zorbalığa maruz kalan ergenler yoğun negatif duygular deneyimleyebilmektedir. Örneğin, kurbanların siber zorbalığa verdikleri duygusal tepkilerin başında stres, kaygı, utanç, üzüntü ve kızgınlık gelmektedir (Caspi ve Gorsky, 2006; Juvonen ve Gross, 2008; Raskauskas ve Stoltz, 2007; Topçu, Erdur-Baker ve Çapa-Aydın, 2008; Türkileri İnselöz ve Uçanok, 2013). Ayrıca internet tacizine hedef olan erkek ergenlerin, hedef olmayan erkek ergenlerle karşılaştırıldığında, depresif semptomlar göstermelerinin sekiz kat daha olası olduğu, kızlarda ise zorbalıkla depresyonun ilişkili olmadığı bulunmuştur (Ybarra, 2004). Diğer bazı çalışmalar ise cinsiyetten bağımsız olarak internette zorbalığa maruz kaldığını bildiren ergenlerde depresyon ve kaygının yaygın semptomlar olduğunu göstermiştir (Arıcak, 2009; Espelage, Bosworth ve Simon, 2001; Kumpulainen, Räsänen ve Puura, 2001; Ybarra, Mitchell, Wolak ve Finkelhor, 2006). Ayrıca internette başkalarını taciz etmenin, gençlerin suçluluk ve depresif semptomlar bildirmeleri ile yüksek oranda ilişkili olduğu dikkati çekmektedir 
(Mitchell, Wolak ve Finkelhor, 2008; Ybarra ve Mitchell, 2004). Diğer taraftan zorba-kurban statüsündeki ergenlerin duygusal problemler açısından en riskli durumda olduğu pek çok araştırmada vurgulanmıştır (Arıcak, 2009; Flaspohler, Elfstrom, Vanderzee, Sink ve Birchmeier, 2009; Wolak, Mitchell ve Finkelhor, 2007).

Yukarıda aktarılan bulgular 1şığında, sanal ortamda deneyimlenen zorbalığın aynı zamanda ergenin hayatını anlamlı hale getiren pozitif içsel gücünü de olumsuz yönde etkileyebileceği öne sürülebilir. Bireysel iyilik hali, bireyin yaşadığı olaylara verdiği pozitif duygusal tepkileri ya da yaşamdan alınan doyum gibi bilişsel yargıları içermektedir (Myers ve Diener, 1995). Yaşam doyumunun çocuklar ve ergenlerde duygusal ve sosyal işlevsellikle pozitif yönde ilişkili olduğuna işaret eden araştırma bulguları mevcuttur (Huebner, 2004). Yaşamın çeşitli alanlarına ilişkin olumlu değerlendirmelerin artmasının yaşamdan alınan doyumu ve genel bireysel iyilik halini arttırdığı düşünülmekte; aile, okul ve akran çevresine ilişkin algılanan doyumun azalmasının ergenin olumsuz davranışlara dahil olma sıklığıyla ilişkili olduğu görülmektedir (Flaspohler ve ark., 2009; Hilooğlu, 2009). Bu bağlamda yürütülen çalışmalarda okulda zorbalığa maruz kalan ergenlerin okula bağlılıklarının daha düşük düzeyde olduğu, akranlarından daha az destek algıladıkları ve bu durumun da yaşamdan alınan düşük doyumla ilişkili olduğu gözlenmiştir (Hilooğlu, 2009; Valois, Kerr ve Huebner 2012; You ve ark., 2008). Zorbalığa maruz kalanların yanı sıra, zorbalık uygulayan ergenlerin de yaşamdan aldıkları doyumun azaldığı gözlenmiştir (Flaspohler ve ark., 2009).

Siber zorbalık ve yaşam doyumu arasındaki ilişkiye dair sınırlı sayıdaki çalışmada da siber zorbalığa hedef olanların (Moore, Huebner ve Hills, 2012; Navarro, Ruiz-Oliva, Larrañaga, ve Yubero, 2015) ve zorbalık uygulayanların (Moore ve ark., 2012) daha düşük düzeyde yaşam doyumu rapor ettikleri gözlenmiştir. Yaşamlarına ilişkin daha az doyum algılayan ergenlerin internet kullanımları sırasında kişisel bilgilerin paylaşılması, internette tanışılan kişilerle dışarıda da görüşülmesi, istenmeyen ve taciz edici konuşmalara devam edilmesi gibi riskli davranışlarda bulunma olasılıklarının daha yüksek olduğunu ortaya koyan çalışmalar da mevcuttur (Livingstone ve Helsper, 2007).

Tüm bulgular 1şığında ergenlerin gelişimsel sonuçları üzerinde anne babaların etkilerine ilişkin anlayışı genişletecek araştırmalara ihtiyaç olduğu açıktır. Bu noktadan hareketle, araştırmanın temel amacı ilk ve orta ergenliği temsil eden gelişimsel dönemde algılanan ebeveyn izlemesi ile yaşam doyumu arasındaki ilişkiyi ve bu ilişkide siber 
zorbalığga dahil olmanın aracı rolünü ergenin cinsiyetine göre incelemektir. Belirlenen amaç doğrultusunda aşağıdaki hipotezler oluşturulmuştur:

H1. Ergenin ebeveynlerinden algıladığı izleme davranışı sanal ortamda zorbalık uygulama ve zorbalığa maruz kalma ile negatif yönde ilişkili olacaktır.

H2. Ergenin ebeveynlerinden algıladığı izleme davranışı yaşamın farklı alanlarından alınan doyum ile pozitif yönde ilişkili olacaktır.

H3. Algılanan ebeveyn izlemesi ile yaşam doyumu arasındaki ilişkide siber zorbalık uygulama ve siber zorbalığa maruz kalma aracı bir role sahip olacak ve bu aracı rol ergenin cinsiyetine göre farklılaşacaktır.

Ancak, sanal ortamda zorbalığa dahil olmada cinsiyet açısından elde edilen bulguların çelişkili olması (örn., Baldry ve ark., 2019; Low ve Espelage, 2013) nedeniyle yukarıda öngörülen bağlantıların ergenin cinsiyetine göre hangi yönde değişeceğine ilişkin hipotez oluşturulmamıştır. Bu nedenle hipotezler her iki cinsiyet için ayrı ayrı sınanmıştır.

\section{YÖNTEM}

\section{Örneklem}

Bu çalışma, ilk ve orta ergenlik döneminde okul ortamında ve sanal ortamda deneyimlenen zorbalığg farklı yönleriyle ele alan kapsamlı bir projenin bir bölümünü oluşturmaktadır. Araştırmanın örneklemini 6 farklı şehir merkezinde (Ankara, İstanbul, Hatay, Mersin, Gaziantep ve Malatya) yaşayan, 2009-2010 eğitim-öğretim yılında ortaokul ve liseye devam eden öğrenciler oluşturmuştur. Araştırmada toplam 1432 ergene ulaşılmış; ancak cinsiyetini belirtmeyen ve aşırı değerler analizi ile belirlenen 37 ergen analizlere dahil edilmemiştir. Böylelikle örneklemi yaşları 12 ile 18 arasında değişen $\left(\right.$ Ort. $\left._{\text {yaş }}=14.87, S S=2.04\right)$ toplam 1395 ergen (\%47.5'i erkek, \%52.5'i kız) oluşturmuştur. Katılımcıların anne ve babalarının yaklaşık \%60’1 lise ve üzeri eğitim düzeyine sahiptir ve \%59'u kendilerini orta gelir grubunda algılamışlardır.

\section{Veri Toplama Araçları}

Kişisel Bilgi Formu. Katılımcıların demografik özellikleri kişisel bilgi formu ile belirlenmiştir. Cinsiyet, yaş, sınıf düzeyi, anne-babanın mesleği ve eğitim düzeyi ile alg1lanan gelir düzeyine ilişkin bilgiler yer almıştır. 
Sanal/Siber Zorbalık Ölçeği. Son altı ayda internet veya cep telefonu yoluyla maruz kalınan ve/veya bir başkasına uygulanan zorbalık davranışlarını belirlemek için kullanılmaktadır. Ölçek, Siber Zorbalık Envanteri (Erdur-Baker ve Kavşut, 2007; Topçu, 2008) temel alınarak yeniden düzenlenmiş ve psikometrik özellikleri sınanmıştır (Burnukara, 2009; Burnukara ve Uçanok, 2012). Kendini bildirim türünde olan ölçek, 4’lü Likert tipi puanlanmaktadır. Toplam 26 maddeden oluşmakta ve elektronik platformlar, forum siteleri, web siteleri, messenger, cep telefonu ve e-posta yoluyla meydana gelen zorbalık davranışı örneklerini içermektedir (örn., "Internette hakkımda dedikodular/ olumsuz söylentiler yayarlar"). Ölçeğin kurban ve zorba olmak üzere paralel iki formu bulunmaktadır; bu örneklem için Cronbach alfa iç tutarlık katsayıları sırasıyla .92 ve .93’tür (Karlıer-Soydaş ve Uçanok, 2014).

Öğrenciler için Çok Boyutlu Yaşam Doyumu Ölçeği. Ergenlerin yaşamlarının farklı alanlarına ilişkin doyum profilini ortaya koymayı hedefleyen ölçek, Huebner (1994) tarafından geliştirilmiştir. Toplamda 5 alt boyuttan (benlik, okul, arkadaş, aile ve yaşanılan çevreden) oluşmaktadır. 4'lü Likert tipi puanlanan ölçekte toplam 40 madde yer almaktadır (örn., “Ailemle birlikte olmaktan hoşlanırım”). Ölçeğin Türkçeye uyarlama çalışması Irmak ve Kuruüzüm (2008) tarafından gerçekleştirilmiş ve sözü edilen çalışmada öğrencilerin kendilerini 4'lü Likert tipi yerine 5'li Likert tipi ölçek üzerinde değerlendirmeleri istenmiştir. Faktör analizi ile ilgili bulgular, ölçeğin orijinalinde olduğu gibi çoklu faktör yapısına sahip olduğunu ve boyutların birbirinden güvenilir bir biçimde ayrıştığını ortaya koymuştur. Ölçeğin Cronbach alfa iç tutarlık katsayısı benlik için .77, okul için .78, arkadaşlar için .82, aile için .83 ve yaşanılan çevre için .76'dir. $\mathrm{Bu}$ araştırma kapsamında ölçeğin psikometrik özellikleri yeniden incelenmiş, faktör yükleri .30’un altında olan "Okul benim için ilginçtir” ve "Bu şehir kötü insanlarla dolu" maddeleri analizlere dahil edilmemiştir. Ölçeğin mevcut örneklemde Cronbach alfa iç tutarlık katsayıları sırasıyla benlik için .74, okul için .80, arkadaşlar için .82, aile için .86, yaşanılan çevre için .80 olarak bulunmuştur.

Ebeveyn Bilgisi: İzleme Ölçeği. Ölçek, ergenlerin özellikle okul dışındaki hareket ve etkinlikleri ve bunların zamanı ve süresiyle ilgili olarak anne babaların sahip olduğu bilgiyi değerlendirmek amaciyla geliştirilmiştir (Kerr ve Stattin, 2000; Stattin ve Kerr, 2000). 5'li Likert tipi üzerinden (5 - her zaman haberi olur, 1 - hiçbir zaman haberi olmaz) puanlanan ölçekten alınan yüksek puan, ergene göre ebeveyninin daha fazla bilgi sahibi olduğuna işaret etmektedir. Tek faktörden ve toplam 9 maddeden oluşan ölçeğin 
Cronbach alfa iç tutarlık katsayısı .85, test-tekrar test güvenirliği ise .83 olarak bulunmuştur. Uyarlama çalışması sırasında ölçekteki “Geçen ay/gece nerede olduğunu bilmediği oldu mu?" maddesi çıkartılmıştır. Ölçeğin Cronbach alfa iç tutarlık katsayısı .86'dır (Sayil ve ark., 2012).

$\mathrm{Bu}$ araştırmanın amacı doğrultusunda ölçeğe internet ve cep telefonuyla ilgili üç yeni madde eklenmiştir; "Anne ve babamın bilgisayarı/interneti hangi amaçla kulland1ğımdan" "Anne ve babamın cep telefonunu hangi amaçla kullandığımdan" ve "Anne ve babamın internette hangi sitelere girdiğimden" (1-hiçbir zaman haberi olmaz, 5- her zaman haberi olur). Bu üç madde de dahil edilerek toplam 11 maddeye uygulanan temel bileşenler analizi sonucunda toplam değişmenin \%58'ini açıklayan ve .67 ile .83 arasında değişen faktör yüklerine sahip tek faktörlü bir yapı elde edilmiştir. Bu şekilde ölçeğin son halinin Cronbach alfa iç tutarlık katsayısı .93’tür.

\section{İșlem}

Araştırma için Milli Eğitim Bakanlığı ve etik kurul izinleri alındıktan sonra ulaşılabilirliği daha kolay olan altı şehir merkezi seçilmiştir. Her şehir merkezinde ilköğretim ve lisedeki her sınıf düzeyinden öğrencinin temsil edilmesi hedeflenerek okul yönetimleri tarafından çalışmaya katılmayı kabul eden okullara gidilmiştir. Bu şekilde araştırmanın örneklemi uygun örneklem yöntemi (convenience sampling) ile belirlenmiştir. Okul yönetimi tarafından ailelere projenin kapsamı, amacı ve yürütülmesi konusunda gerekli bilgilendirme yapıldıktan sonra uygulamalar, okul yönetimi ve öğretmenlerle ortaklaşa belirlenen ders saatleri içerisinde, sınıf ortamında ve grup halinde gerçekleştirilmiştir. Ergenler ölçekleri yanıtlamaya başlamadan önce araştırmanın amacı hakkında kısaca bilgilendirilmiş; kimliklerinin gizli kalacağı, katılımın gönüllülük esasına dayandığı ve istedikleri takdirde araştırmaya katılmaktan vazgeçebilecekleri söylenmiştir. Ölçeklerin yanıtlanması yaklaşık olarak bir ders saati (45 dakika) içerisinde tamamlanmıştır.

\section{BULGULAR}

\section{Ergenin Cinsiyeti ve Sınıf Düzeyine Göre Siber Zorbalığa Dahil Olma Sıklığı}

Araştırmanın temel analizlerine geçmeden önce ergenlerin siber zorbalığa dahil olma sıklığg incelenmiştir. Cinsiyete ve sınıf düzeyine göre siber zorbalık uygulama ve siber zorbalığa maruz kalma puanlarının farklılaşıp farklılaşmadığını belirlemek için MANOVA uygulanmıştır. Box’s M testi sonucunda varyansların homojenliği varsayımı- 
nın karşılanmadığı görüldüğünden Pillai’s Trace kriteri kullanılmıştır. Elde edilen sonuçlara göre cinsiyet ve sınıf düzeyinin temel etkisi anlamlıdır (sırasıyla Pillai's Trace $=$ $.05, \mathrm{~F}_{(2,1380)}=34.24, p<.001, \eta^{2}=.05$; Pillai's Trace $=.03, \mathrm{~F}_{(12,2762)}=3.62, p<.001, \eta^{2}=$ $.02)$. Post hoc sonuçlarına göre zorbalığa maruz kalma ve uygulama için cinsiyetler arasindaki fark anlamlıdır ( $\operatorname{sirasiyla~} \mathrm{F}_{(1,1381)}=35.08, p<.001, \eta^{2}=.02 ; \mathrm{F}_{(1,1381)}=67.72, p<$ $\left..001, \eta^{2}=.05\right)$. Buna göre, kızların zorbalığa maruz kalma (Ort. $\left.=1.11 ; S S=.21\right)$ ve uygulama $(O r t .=1.05 ; \mathrm{SS}=.15)$ puan ortalamaları erkeklerin zorbalığa maruz kalma $($ Ort. $=1.20 ; S S=.39)$ ve uygulama $($ Ort. $=1.17 ; S S=.39)$ puan ortalamalarından daha düşüktür. Zorbalık uygulama açısından sınıf düzeyine göre anlamlı bir farklılık görülmezken, zorbalığa maruz kalmada anlamlı bir farklılık elde edilmiştir $\left(\mathrm{F}_{(6,1381)}=4.49, p\right.$ $\left.<.001, \eta^{2}=.02\right)$. İleri analize göre zorbalığa maruz kalma için altıncı sınıfların ortalamaları (Ort. $=1.23 ; S S=.45)$, dokuzuncu (Ort. $=1.12 ; S S=.24)$ ve onuncu (Ort. $=$ $1.10 ; S S=.20)$ sinıfların ortalamalarından; sekizinci sınıfların ortalamaları (Ort. = 1.19; $S S=.33)$, onuncu sinifların ortalamalarından $($ Ort. $=1.10 ; S S=.20)$ anlamlı olarak farklılaşmaktadır.

\section{Ebeveyn İzlemesi ile Yaşam Doyumu Arasındaki İlişkide Siber Zorbalığın Aracı Rolünün Sinanması}

$\mathrm{Bu}$ araştırmada ebeveyn izlemesi ile yaşam doyumu arasındaki ilişkide siber zorbalığa maruz kalma ve uygulamanın aracı rolü Yapısal Eşitlik Modeli kullanılarak incelenmiştir. Araştırmanın temel hipotezlerinin test edilmesinden önce araştırma değişkenleri arasındaki ilişkiler Pearson korelasyon katsayısı ile incelenmiştir. Değişkenler arası ilişkilere bakıldığında, beklentiyle uyumlu biçimde, hem kız (aile alt boyutu için $r(2,731)$ $=.47 ; p<.001$; arkadaş alt boyutu boyutu için $r(2,731)=.21 ; p<.001$; okul alt boyutu için $r(2,731)=.27 ; p<.001$; benlik alt boyutu için $r(2,731)=.19 ; p<.001$; yaşanılan çevre alt boyutu için $r(2,731)=.27 ; p<.001)$ hem de erkek ergenlerde (aile alt boyutu için $r(2,657)=.39 ; p<.001$; arkadaş boyutu için $r(2,657)=.20 ; p<.001$; okul alt boyutu için $r(2,657)=.26 ; p<.001$; benlik alt boyutu için $r(2,657)=.22 ; p<.001$; yaşanılan çevre alt boyutu için $r(2,657)=.23 ; p<.001)$ ebeveyn izlemesi, yaşam doyumun tüm alt boyutları ile pozitif ve siber zorbalığa zorba (erkek ergenler için $r(2,657)=-.18$; $p<.001$; k1z ergenler için $r(2,731)=-.19 ; p<.001)$ ve kurban (erkek ergenler için $r(2$, $657)=-.13 ; p<.01 ;$ k1z ergenler için $r(2,731)=-.18 ; p<.001)$ olarak dahil olma ile negatif yönde ilişkilidir. Siber zorbalığa maruz kalma ile yaşam doyumunun tüm alt boyutları (benlik alt boyutu dişında) hem kız (aile alt boyutu için $r(2,731)=-.13 ; p<.01$; arkadaş alt boyutu için $r(2,731)=-.18 ; p<.001$; okul alt boyutu için $r(2,731)=-.14 ; p$ 
$<.001$; yaşanılan çevre için $r(2,731)=-.13 ; p<.01)$ hem de erkek ergenlerde negatif yönde ilişkilidir (aile alt boyutu için $r(2,660)=-.10 ; p<.05$; arkadaş alt boyutu için $r(2,660)=-.15 ; p<.001$; okul alt boyutu için $r(2,660)=-.14 ; p<.001$; yaşanılan çevre için $r(2,660)=-.17 ; p<.001)$. Siber zorbalık uygulama ile yaşam doyumu arasındaki ilişki incelendiğinde ise k1z ergenlerde aile $(r(2,731)=-.08 ; p<.05)$ ve okul alt boyutları negatif yönde ilişkiliyken $(r(2,731)=-.11 ; p<.01)$, erkek ergenlerde okul $(r(2$, $660)=-.14 ; p<.001)$, arkadaş $(r(2,660)=-.12 ; p<.01)$ ve yaşanılan çevre alt boyutları negatif yönde ilişkilidir $(r(2,660)=-.13 ; p<.01)$. Son olarak, siber zorbalığa maruz kalma ile uygulama arasinda hem erkek $(r(2,660)=.67 ; p<.001)$ hem k1z ergenlerde pozitif yönde $(r(2,731)=.48 ; p<.001)$ anlamlı ilişki bulunmuştur (bkz. Tablo 1$)$.

Tablo 1. Kız ve Erkek Ergenler için Bütün Değişkenlerin Pearson Korelasyon Katsayıları, Ortalama ve Standart Sapma Değerleri

\begin{tabular}{|c|c|c|c|c|c|c|c|c|c|c|}
\hline Değişkenler & 1 & 2 & 3 & 4 & 5 & 6 & 7 & 8 & $\begin{array}{c}\text { Erkek ergen } \\
\text { Ort. (SS) }\end{array}$ & $\begin{array}{c}\text { Kiz ergen } \\
\text { Ort. (SS) }\end{array}$ \\
\hline 1. Ebev. İz. & - & $.47 * * *$ & $.21 * * *$ & $.27 * * *$ & $.19 * * *$ & $.27 * * *$ & $-.18 * * *$ & $-.19 * * *$ & $3.63(1.02)$ & $4.10(.85)$ \\
\hline 2. YD (Aile) & $.39 * * *$ & - & $.44 * * *$ & $.33 * * *$ & $.46^{* * *}$ & $.48 * * *$ & $-.13 * *$ & $-.08 *$ & $4.18(.78)$ & $4.20(.87)$ \\
\hline $\begin{array}{l}\text { 3. YD } \\
\text { (Arkadaş) }\end{array}$ & $.20 * * *$ & $.37 * * *$ & - & $.41 * * *$ & $.57 * * *$ & $.38 * * *$ & $-.18 * * *$ & -.04 & $4.12(.72)$ & $4.20(.71)$ \\
\hline 4. YD (Okul) & $.26 * * *$ & $.36 * * *$ & $.31 * * *$ & - & $.33 * * *$ & $.38 * * *$ & $-.14 * * *$ & $-.11 * *$ & $3.42(.85)$ & $3.54(.88)$ \\
\hline $\begin{array}{l}\text { 5. YD } \\
\text { (Benlik) }\end{array}$ & $.22 * * *$ & $.48 * * *$ & $.53 * * *$ & $.29 * * *$ & - & $.30 * * *$ & -.03 & .02 & $4.21(.60)$ & $4.23(.63)$ \\
\hline $\begin{array}{l}\text { 6. YD } \\
\text { (Çevre) }\end{array}$ & $.23 * * *$ & $.44 * * *$ & $.38 * * *$ & $.36^{* * *}$ & $.38 * * *$ & - & $-.13 * *$ & -.03 & $3.68(.90)$ & $3.57(.91)$ \\
\hline 7. SK & $-.13 * *$ & $-.10 *$ & $-.15^{* * *}$ & $-.14 * * *$ & -.07 & $-.17 * * *$ & - & $.48 * * *$ & $1.20(.39)$ & $1.11(.21)$ \\
\hline 8. SZ & $-.18 * * *$ & -.07 & $-.12 * *$ & $-.14 * * *$ & -.06 & $-.13 * *$ & $.67 * * *$ & - & $1.17(.39)$ & $1.05(.15)$ \\
\hline
\end{tabular}

Not. Tablonun alt yarısındaki değerler erkek ergenlere, üst yarısındaki değerler kız ergenlere aittir; YD: Yaşam Doyumu, Ebev. İz.: Ebeveyn İzlemesi, SK: Sanal Kurban, SZ: Sanal Zorba; ${ }^{*} p<.05 .{ }^{* *} p<.01 .{ }^{* * *} p<.001$

Analiz Yöntemi. Araştırmanın aracı değişkenine yönelik hipotezlerinin sınanmasıyla ilgili analizlerde Lisrel 8.54 (Jöreskog ve Sörbom, 1999) programı kullanılmıştır. Veri incelendiğinde zorbalık ölçümlerinin doğası gereği tek yönlü ve çok yönlü normallik sayıltısının sağlanamadığı görülmüş, bu nedenle asimptotik kovaryans matriksi kullanılmış ve Satorra-Bentler Ki Kare (SBS_ $\chi^{2}$; Satorra ve Bentler, 1994) değeri temel alınmıştır. Önerilen model ile verinin uyumu RMSEA (Root-Mean-Square Error of Approximation), CFI (Comparative Fit Indices) ve SRMR (Standardized Root Mean Square Residual) göstergeleriyle değerlendirilmiştir. Bu araştırma için kabul edilebilir uyum indeksleri RMSEA ve SRMR için .08 ve altı (Hu ve Bentler, 1999); CFI için 95 ve üzeri olarak belirlenmiş ve aracı etkideki düşme Sobel testi ile (Sobel, 1982) değerlendirilmiştir. 
Ölçüm Modeli Sonuçları. Siber zorbalık (zorbalık uygulama ve zorbalığa maruz kalma) ve ergenin cinsiyetine göre (kız, erkek) ayrı ayrı üretilen ölçüm modellerinde tek boyutlu yapıya sahip olan ebeveyn izlemesi ve siber zorbalığa dahil olma değişkenleri için madde parselleme (Hau ve Marsh, 2004) yöntemi kullanılmıştır. Buna göre ebeveyn izlemesi ve siber zorbalığa dahil olma seçkisiz olarak oluşturulan üç parsel değişkenle; yaşam doyumu ise çok boyutlu yapısından dolayı benlik, okul, arkadaş, aile ve yaşanılan çevre alt ölçeklerini oluşturan beş boyutla temsil edilmiştir. Böylece model üç gizil değişken ve 11 gösterge üzerinden test edilmiştir. Sonuçta hem kızlarda hem de erkeklerde üretilen ölçüm modelinin veri ile görece iyi uyum gösterdiği görülmüştür. Bu noktadan hareketle ölçüm modelinin modifikasyon indeksleri incelenmiştir. Modelde değişiklik indeksi farklı gizil değişkenlerin göstergeleri olan ebeveyn izlemesi ile aileye dair yaşam doyumu arasındaki hataların eklenerek ilk modelin kuvvetlendirilmesini önermiştir. Bu durumun "Anne babamla zaman geçirmekten hoşlanırım” gibi maddelerin yer aldığı yaşam doyumu ölçümü ile "Anne ve babamın boş zamanlarımda ne yaptığımdan haberi olur” gibi maddelerin yer aldığ1 ebeveyn izlemesi ölçümünün aynı hedef kişiye yönelik doldurulmasından kaynaklandığı düşünülmüştür. Bu nedenle aile alt boyutu ilerleyen analizlere dahil edilmemiştir. Böylece model üç gizil değişken ve 10 gösterge üzerinden test edilmiştir.

Siber zorbal1k uygulama $(z o r b a)$ modelinin hem k1zlarda $\left[\operatorname{SBS}_{-} \chi^{2}(32, N=733)=\right.$ $110.68, p<.001, \mathrm{RMSEA}=.06, \mathrm{SRMR}=.05, \mathrm{CFI}=.97]$ hem de erkeklerde [SBS_ $\chi^{2}$ $(33, N=662)=112.32, p<.001, \mathrm{RMSEA}=.06, \mathrm{SRMR}=.04, \mathrm{CFI}=.97]$ veri ile iyi uyum gösterdiği ve ölçüm modelinin uyum indekslerinin kabul edilebilir sınırlar içerisinde olduğu görülmektedir. Ölçüm modelindeki gizil değişkenler arasındaki yapısal korelasyonlar incelendiğinde, kız ve erkek ergenlerde algilanan ebeveyn izlemesinin siber zorbalık uygulama ile olumsuz, yaşam doyumuyla olumlu yönde; siber zorbalık uygulamanın ise sadece erkeklerde yaşam doyumuyla olumsuz yönde ilişkili olduğu görülmüştür. Siber zorbalığa maruz kalma (kurban) modelinin hem kılarda [SBS_ $\chi^{2}$ $(32, N=733)=114.19, p<.001, \mathrm{RMSEA}=.06, \mathrm{SRMR}=.04, \mathrm{CFI}=.98]$ hem de erkeklerde $\left[\right.$ SBS_ $\chi^{2}(33, N=662)=142.24, p<.001$, RMSEA $=.06$, SRMR $=.04$, CFI $=$ 97] veri ile iyi uyum gösterdiği ve ölçüm modelinin uyum indekslerinin kabul edilebilir sınırlar içerisinde olduğu görülmektedir. Ölçüm modelindeki gizil değişkenler arasındaki yapısal korelasyonlar incelendiğinde, kız ve erkek ergenlerde algılanan ebeveyn izlemesinin siber zorbalığa maruz kalma ile olumsuz, yaşam doyumu ile olumlu yönde; 
siber zorbalığa maruz kalmanın ise yaşam doyumuyla olumsuz yönde ilişkili olduğu görülmüştür.

\section{Yapısal Eşitlik Modeli Sonuçları.}

Doğrudan Etkiler. Zorba ve Kurban modelleri için ebeveyn izlemesi ve yaşam doyumu arasındaki doğrudan ilişki kız ve erkek ergenler için ayrı ayrı yapılan analizle incelenmiş; hem kızlarda [SBS_ $\chi^{2}(13, N=733)=80.00, p<.001$, RMSEA $=.08$, SRMR $=.05, \mathrm{CFI}=.97]$ hem de erkeklerde $\left[\mathrm{SBS}_{-} \chi^{2}(13, N=662)=60.20, p<.001\right.$, RMSEA $=.07, \mathrm{SRMR}=.04, \mathrm{CFI}=.98]$ modelin veri ile iyi uyum gösterdiği görülmüştür. Ebeveyn izlemesinin ergenin yaşam doyumundaki varyansın kızlarda \%12'sini, erkeklerde ise \%13'ünü açıkladığg görülmüştür. Ebeveyn izlemesi hem kızlarda hem de erkeklerde yaşam doyumunu $\left(\beta_{\mathrm{k} ı z}=.35, p<.001 ; \beta_{\text {erkek }}=.36, p<.001\right)$ pozitif yönde yordamaktadır.

Aracı Etkiler. Ebeveyn izlemesi ve yaşam doyumu arasındaki ilişkiye siber zorbalık uygulama eklenerek oluşturulan aracı etki modeli (zorba modeli) kız ve erkek ergenlerde ayrı ayrı incelenmiş, hem kızlarda $\left[\mathrm{SBS}_{-} \chi^{2}(32, N=733)=110.68, p<.001, \mathrm{RM}-\right.$ $\mathrm{SEA}=.06, \mathrm{SRMR}=.05, \mathrm{CFI}=.97]$ hem de erkeklerde $\left[\mathrm{SBS} \_\chi^{2}(32, N=662)=75.10\right.$, $p<.001, \mathrm{RMSEA}=.05, \mathrm{SRMR}=.04, \mathrm{CFI}=.98]$ modelin veri ile iyi uyum gösterdiği görülmüştür. Kız ve erkek ergenlerde siber zorbalık modeli için elde edilen ilişkiler ve gizil değişkenlerde açıklanan varyans değerleri Şekil 1'de gösterilmiştir.

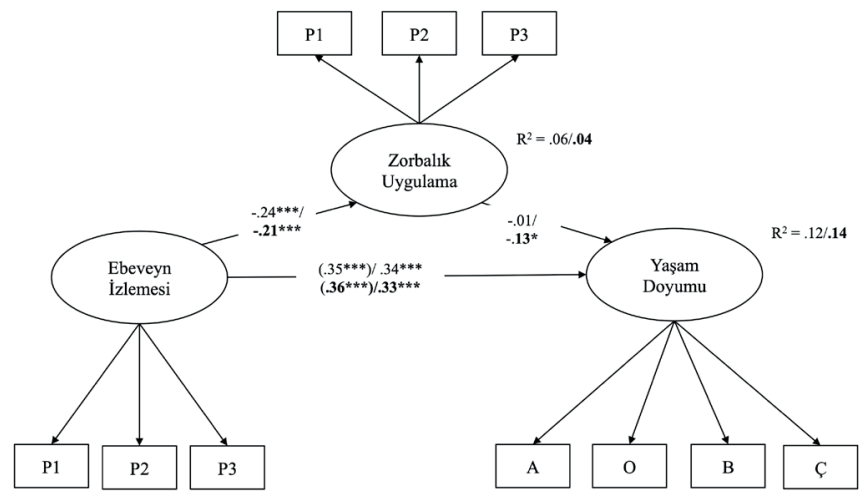

Şekil 1. Kız ve Erkeklerde Zorba için Ölçüm Modeli ve Gizil Değişkenler Arasındaki Yapısal Korelasyonlar

Not. Koyu renkli değerler erkek örneklemine, parantez içindeki değerler doğrudan etkilere aittir; $R^{2}$ : Srrasıyla kız ve erkek modellerinde gizil değişkende açıklanan varyansı göstermektedir. P1: Birinci parsel değişken, A: Arkadaşlar, O: Okul, B: Benlik, Ç: Çevre; *p $<.05,{ }^{* *} \mathrm{p}<.01$, $* * * \mathrm{p}<.001$.

Hem kızlarda hem de erkeklerde ebeveynin izleme davranışının zorbalık uygulamayı negatif yönde, yaşam doyumunu ise pozitif yönde yordadı̆̆ı; sadece erkeklerde zor- 
balık uygulamanın yaşam doyumunu negatif yönde yordadığı bulunmuştur. Ancak kızlarda siber zorbalık uygulama ile yaşam doyumu arasındaki ilişkinin anlamsız olmasından dolayı aracı ilişki test edilmemiştir. Ebeveynin ergeni izleme davranışı ve yaşam doyumu arasındaki ilişkide zorbalığın aracı rolü incelendiğinde, erkeklerde algılanan ebeveyn izlemesi ve yaşam doyumu arasındaki doğrudan ilişkinin siber zorbalığın eşitliğe dahil edilmesiyle .36 'dan .33 'e düştüğü ve bu düşüşün anlamlı olduğu görülmüştür $\left(\mathrm{z}_{\text {erkek }}=2.13, p<.01\right)$. Sonuçta erkeklerde ebeveynin izleme davranışı ve yaşam doyumu arasındaki ilişkiye ergenin siber zorbalık uygulamasının kısmi olarak aracılık ettiği bulunmuştur.

Ebeveyn izlemesi ve yaşam doyumu arasındaki ilişkiye siber zorbalığa maruz kalma eklenerek oluşturulan aracı etki modeli (kurban modeli) kız ve erkek ergenlerde ayrı ayrı incelenmiş, hem kızlarda $\left[\mathrm{SBS} \_\chi^{2}(32, N=733)=114.19, p<.001, \operatorname{RMSEA}=.06\right.$, $\mathrm{SRMR}=.04, \mathrm{CFI}=.98]$ hem de erkeklerde $\left[\mathrm{SBS}_{-} \chi^{2}(32, N=662)=97.62, p<.001\right.$, $\mathrm{RMSEA}=.06, \mathrm{SRMR}=.04, \mathrm{CFI}=.98]$ modelin veri ile iyi uyum gösterdiği görülmüştür. Kız ve erkek ergenlerde siber zorbalığa maruz kalma modeli için elde edilen ilişkiler ve gizil değişkenlerde açıklanan varyans değerleri Şekil 2'de gösterilmiştir.

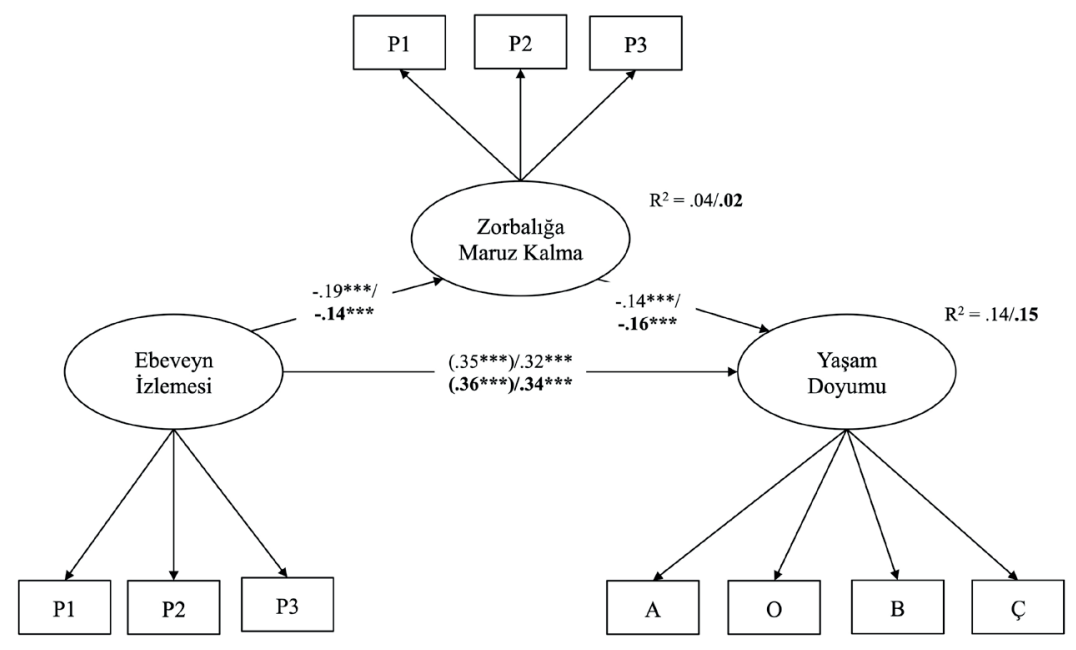

Şekil 2. Kız ve Erkeklerde Kurban için Ölçüm Modeli ve Gizil Değişkenler Arasındaki Yapısal Korelasyonlar

Not. Koyu renkli değerler erkek örneklemine, parantez içindeki değerler doğrudan etkilere aittir; $R^{2}$ : Sırasıyla kız ve erkek modellerinde gizil değişkende açılkanan varyansı göstermektedir. P1: Birinci parsel değişken, A: Arkadaşlar, O: Okul, B: Benlik, Ç: Çevre; *p $<.05,{ }^{* *} \mathrm{p}<.01$, $* * * \mathrm{p}<.001$.

Hem erkeklerde hem de kızlarda ebeveynin izleme davranışının zorbalığa maruz kalmayı negatif yönde, yaşam doyumunu ise pozitif yönde; zorbalığa maruz kalmanın 
da yaşam doyumunu negatif yönde yordadığı bulunmuştur. Sonuçta ebeveynin izleme davranışı ile yaşam doyumu arasındaki doğrudan ilişkinin kızlarda .35'den .32'ye; erkeklerde .36'dan .34'e düştüğü ve bu düşüşün anlamlı olduğu görülmüş $\left(\mathrm{z}_{\mathrm{k} 1 z}=2.38, p<\right.$ $.01 ; \mathrm{z}_{\text {erkek }}=2.43, p<.01$ ); hem kızlarda hem de erkeklerde ebeveynin izleme davranış1 ile yaşam doyumu arasındaki ilişkiye siber zorbalığa maruz kalmanın kısmi olarak arac1lık ettiği bulunmuştur.

\section{TARTIŞMA}

$\mathrm{Bu}$ çalışmanın temel amacı ergenin algıladığı ebeveyn izlemesi ile yaşam doyumu arasındaki ilişkide siber zorbalığa dahil olmanın aracı rolünü incelemektir. Elde edilen bulgular, araştırmanın aracı etki hipotezini destekleyerek, sanal ortamda sergilenen zorbaca davranışların, algılanan ebeveyn izlemesi ile yaşam doyumu arasındaki pozitif yöndeki ilişkiyi kısmen açıkladığını göstermiştir. Araştırmanın diğer hipotezleri algılanan ebeveyn izlemesinin doğrudan etkileriyle ilgilidir. Buna göre beklentiyle uyumlu biçimde, ebeveynlerinden daha fazla izleme algılayan ergenler daha yüksek düzeyde yaşam doyumu bildirmiştir. Benzer şekilde, ebeveyn izlemesini daha yüksek algılayan ergenlerin, sanal ortamda zorbaca davranışlara daha az dahil oldukları gözlenmiştir.

Araştırmanın doğrudan etki hipotezleri ile ilgili bulgular, hem kızlarda hem de erkeklerde algılanan ebeveyn izlemesinin zorbalığa hedef olmayı ve zorbaca davranışlar sergilemeyi azalttı̆̆ını göstermiştir. Bu bulgu, ergenlik döneminde çocuğa sahip anne babaların aktif izleme davranışlarının, yani ergenin nerede, ne zaman ve kimlerle ne yapıyor olduğuna dair bilgi sahibi olmasının siber zorbalık gibi problem davranışlara dahil olmada koruyucu bir faktör olduğunu gösteren çalışmaların bulgularıyla tutarlı görünmektedir (Floros ve ark., 2013; Low ve Espelage, 2013; Navarro ve ark., 2013; Nocentini ve ark., 2018; Shapka ve Law, 2013). Ancak ebeveyn izlemesi ve siber zorbalık ilişkisini ele alan çalışmalar incelendiğinde çelişkili bulgulara da rastlanmaktadır. Buna göre, bu çalışmada rapor edilen bulgunun aksine, ebeveyn izlemesinin siber zorbalığa dahil olmayı arttırdığına işaret eden çalışmalar da mevcuttur (Álvarez-García ve ark., 2015; Low ve Espelage, 2013; Sasson ve Mesch, 2014). Bu yönde elde edilen bulgular, bazı araştırmalarda, ebeveynin aktif izleme davranışlarının yerine kısıtlayıcı ebeveynlik uygulamalarının ele alınmasından kaynaklanıyor olabilir. Bir başka deyişle, izlemenin siber zorbalığa dahil olmada bir risk faktörü olabileceğini öne süren araştırmacılar, ebeveynlerin geleneksel olarak daha sıklıkla uyguladıkları ve ergenin özerkliğini kısıtlayıcı 
uygulamalara atıf yaparak (Laird ve ark., 2018), ergenlik döneminin bir özgürlük arayış1 ve ergenin kendi kimliğini oluşturabilmesi için özerkleşme hareketlerinin başladığı dönem olduğuna dikkat çekmektedir (Noom, Deković ve Meeus, 1999). Ergenler, bu dönemde kendi sınırlarını keşfeder ve ilk kez birtakım sorumlulukları deneyimlerler. Buna bağlı olarak, davranışlarının aşırı derecede kontrol edildiğini ve kişisel sınırlarının aşıldığını hisseden ergenlerin negatif duygusal tepkiler deneyimledikleri gözlenmiştir (Hawk, Hale, Raaijmakers ve Meeus, 2008; Kakihara, Tilton-Weaver, Kerr ve Stattin, 2010; Laird ve ark., 2018). Ergenin, anne babasını bir 'helikopter' gibi kendisini sürekli kontrol eden bir rolde algılamasının depresyon ve kaygı gibi içselleştirme problemlerine ve düşük düzeyde bireysel iyilik haline yol açtığı gösterilmiştir (Schiffrin ve ark., 2014). Benzer şekilde, bazı ergenler ebeveynlerinin 'Facebook hesaplarını takip etmesi' gibi izleme faaliyetlerini uygunsuz ve utanç verici bulmuşlardır (Bowler, Knobel ve Mattern, 2015). Dolayısıyla ebeveyn izlemesi ve siber zorbalık arasındaki ilişkiye dair çelişkili gibi görünen bulguların, ebeveyn izlemesinin çok boyutlu yapısından ve araştırmalarda kullanılan yöntemsel farklılıklardan kaynaklanabileceğine dikkat çekilmektedir (Baldry ve ark., 2019).

Ebeveyn izlemesine dair farklı yaklaşımlar olsa da ebeveynin ergenin nerede ve kimlerle olduğuna ve hangi aktivitelerde bulunduğuna dair farkındalığının ve bilgi sahibi olmasının ergenin daha az problem davranışlarda bulunması ile ilişkili olduğuna dair bir fikir birliği söz konusudur (Patterson ve Stouthamer-Loeberi 1984; Pettit, Laird, Dodge, Bates ve Criss, 2001; Stattin ve Kerr, 2000). Öte yandan, ergene sorular sorma türünden değerlendirici uygulamalar ile kısıtlayıcı kurallar konulmasını içeren izleme yöntemlerinin ergenin problem davranışları ile ilişkisine dair bulgular çeliş̧ilidir (Laird ve ark., 2018). Bu nedenle, bu çalışmada izleme uygulamaları standart İzleme Ölçeği (Kerr ve Stattin, 2000; Say1l ve ark., 2012) kullanılarak ebeveynin bilgisini kapsayacak şekilde (Hong ve ark., 2016) kavramsallaştırılmıştır. Bunun yanı sıra, ergenin internet ve cep telefonu üzerinden gerçekleştirdiği çevrimiçi faaliyetlerine dair ebeveyn bilgisi de ölçüme dahil edilmiştir. Dolayısıyla bu çalışmada ebeveynin ergenin elektronik ortamdaki aktiviteleri hakkında bilgi sahibi olması aktif izlemeyi içermekte ve bu yöntem, kısıtlayıcı ebeveynlik uygulamalarından oldukça farklılaşmaktadır. Örneğin, kısıtlayıcı uygulamaların aksine, elektronik ortamda güvenlik ve internetin faydalı kullanımı konusunda bilgi alışverişine dayalı olarak kurallar belirlenmesi gibi izleme uygulamalarının sanal ortamda zorbalığa maruz kalmaya karşı koruyucu bir rolü olduğu gösterilmiştir (Chang ve ark., 2015; Floros ve ark., 2013; Hemphill ve Heerde, 2014; Navarro ve ark., 2013). 
Zorbalık gibi saldırganca davranışlar aynı zamanda ahlaki gelişim ile de yakından ilişkilidir (Arsenio, Adams ve Gold, 2009; Perren, Gutzwiller-Helfenfinger, Malti ve Hymel, 2012). Toplumsal ahlakın temeli olan diğerine karşı sorumluluk hissetme becerisi, öncelikle kendisini ebeveynine karşı sorumlu hissetme olarak kendini gösterir (Smetana, 1997). İnternet ortamında, genellikle doğrudan ve yüz yüze iletişimin olmaması kimi zaman karşıdaki kişiye nezaket gösterilmesi gibi sosyal sorumluluk hissini azaltabilmekte ve ahlaki muhakemenin askıya alınması söz konusu olabilmektedir (Kowalski ve ark., 2014; Wachs, 2012). Örneğin, yakın zamanlı bir araştırmada, bu ahlaki geri çekilmenin (moral disengagement) ebeveyn izlemesi ve okul iklimi ile siber zorbalık arasındaki ilişkiye aracılık ettiği gösterilmiştir (Bartolo, Palermiti, Servidio ve Musso, 2019). Buna göre, ebeveyni tarafından izlendiğinin bilincinde olan ergen, diğerlerine karşı daha az sosyal sorumluluk hissetse bile, ebeveynine olan sorumluluğu devam edebilir. Ayrıca sıcak ve uyumlu bir aile ortamı (White, 1996) ve ebeveynin yüksek ahlaki değerlere sahip olması (White ve Matawie, 2004) ile ergenin ahlaki muhakeme becerisi arasında da pozitif yönde ilişkiler olduğu gözlenmiştir. Bu bağlamda, ergenlerin toplumsal ve evrensel etik değerleri kazanımında ebeveynlerin rehberliğine ihtiyaç duydukları ve siber zorbalık gibi toplumsal dayanışmaya zarar verici antisosyal davranışların azaltılmasında ebeveynlerin önemli rolü olduğu düşünülmektedir.

Ebeveyn izlemesi ile yaşam doyumu arasındaki doğrudan ilişki incelendiğinde, hem kızlarda hem de erkeklerde ebeveynin izleme davranışının yaşam doyumunu arttırdı̆̆ gözlenmiştir. Bu sonuç, alan yazında ebeveyn izlemesi ve yaşam doyumu arasındaki ilişkiye dikkat çeken az sayıda araştırmaya katkı sağlamıştır (Suldo ve Huebner, 2004). Elde edilen bu bulgu, ebeveyn ile çocuk arasındaki sıcak ve olumlu ilişkilerin ergenin yaşamdan aldığı doyumu olumlu yönde etkilediğini gösteren bulguları da destekler niteliktedir (Boniel-Nissim ve ark., 2015; Jacobson ve Crockett, 2000). Öte yandan, siber zorbalık gibi ergenin uyum sorunları bugüne dek sıklıkla içselleştirme ve dışsallaştırma problemleri gibi risk faktörleri ile ilişkili olarak ele alınmıştır (örn., Arıcak, 2009; Caspi ve Gorsky, 2006). Oysaki ergenin psikolojik sağlığının desteklenmesi ve psikolojik dayanıklılığının arttırılması için yaşamdan alınan doyum ve algılanan mutluluk gibi koruyucu faktörlerin önemine de vurgu yapılmaktadır (Diener, Suh, Lucas ve Smith, 1999; Duy ve Yıldız, 2020; Lyubomirsky, King ve Diener, 2005). Bu açıdan elde edilen bulgular 1şı̆̆ında, ebeveyn izlemesinin ergenin genel psikolojik iyilik haline ve sağlıklı bir yetişkin olarak gelişimine önemli katkıları olduğunu vurgulamak yerinde olacaktır. 
Araştırmanın aracı ilişki hipotezine dair temel bulguları, hem erkek hem kız ergenlerde ebeveyn izlemesi ve yaşam doyumu arasındaki ilişkide siber zorbalığa maruz kalmanın kısmen aracılık ettiğini gösterirken; sadece erkek ergenlerde siber zorbalık uygulamanın bu ilişkiye kısmen aracılık ettiğini göstermektedir. Buna göre, erkek ergenlerin ebeveynlerinden algıladıkları izlemenin artması, internet ortamında hem kurban hem de zorba olmayı bir ölçüde azaltarak yaşamın çeşitli alanlarına dair doyumunu arttırmaktadır. Bazı araştırmalarda siber zorbalığa dahil olma açısından erkek ergenlerin kız ergenlere göre daha yüksek oranda risk altında olduğu rapor edilmiştir (örn., Baldry ve ark., 2019). Ayrıca öfke ve saldırganlık gibi dışsallaştırma problemlerinin erkek ergenlerdeki yaygınlığı bilinmektedir (örn., Card, Stucky, Sawalani ve Little, 2008). Buna rağmen, bu çalışmadan elde edilen bulgular her iki cinsiyetin de ebeveyn izlemesinin koruyucu etkilerinden yararlanarak, algılanan ebeveyn bilgisinin siber zorbalığa dahil olmalarını azalttığını göstermiştir. Buna göre, ebeveynin ergenin aktiviteleri hakkında bilgi sahibi olması ve elektronik ortamlardaki faaliyetlerini takip etmesi, erkek ergenlerin sanal ortamda olumsuz davranışlarda bulunmasını bir ölçüde azaltarak ergenlerin iyilik haline olumlu katkıda bulunmaktadır. Kızlarda ise daha fazla izleme algılanması sanal ortamda zorbaca davranışlara maruz kalmayı bir ölçüde azaltarak yaşamın farklı alanlarından alınan doyumu arttırmıştır. Hatırlanacağı gibi, kız ergenlerin siber zorbalık uygulaması ile yaşam doyumu arasında bir ilişki olmadığı görülmüştü. Bu sebeple, siber zorbalık uygulamanın aracı etkisi kız ergenlerde test edilmemişti. Elde edilen bu bulguyu, kız ergenlerin çok daha düşük düzeyde zorbalık uyguladıklarını rapor etmesi ile belirli ölçüde açıklamak mümkündür. Bu çalışmada siber zorbalığa dahil olma ve ele alınan ilişkiler açısından kız ve erkek ergenlere göre elde edilen bulgular, ilgili alan yazında dikkat çekildiği gibi ergenin cinsiyetinin önemli bir faktör olduğunu ortaya koymaktadir.

Ulaşılabilen kaynaklar çerçevesinde, ebeveyn izlemesi ile yaşam doyumu ilişkisinde siber zorbalığın aracı etkisini inceleyen bir çalışmaya rastlanmamıştır. Bu nedenle araştırmanın bulguları, ergenlerin aktif izleme uygulamalarını bir tür ebeveyn ilgisi olarak değerlendirerek sanal ortamdaki zorbaca davranışlardan kendilerini koruduklarını, buna bağlı olarak da öznel iyilik hallerinin desteklendiği öne sürülebilir. Bunun yanı sıra, elde edilen bulgular, siber zorbalığa dahil olma ile yaşamdan alınan doyum arasında negatif ilişkiler olduğunu gösteren sınırlı sayıdaki çalışmanın bulguları ile de paralellik göstermektedir (Moore ve ark., 2012; Navarro ve ark., 2015). Öte yandan, ebeveyn izlemesi 
ve siber zorbalığa dahil olma arasındaki ilişkiler ve bu ilişkilerin yaşam doyumunu açıklamaya olan katkısı çok güçlü olmamakla birlikte ileride yapılacak olan çalışmalar için yol gösterici niteliktedir. Siber zorbalığga dahil olmanın ebeveyn izlemesi ile yaşam doyumu arasındaki ilişkide kısmi aracılık etkisinin çok güçlü olmaması, bu ilişkide diğer bazı faktörlerin de rol oynayabileceğini düşündürmektedir. Örneğin, ebeveyn izlemesi ile siber zorbalığı da kapsayan antisosyal davranışlar arasındaki ilişkide ebeveyn-ergen arasındaki çatışmalı ilişkinin (Knoester, Haynie ve Stephens, 2006; Morrison, Robertson, Laurie ve Kelly, 2002) ve ergenin diğer psikolojik uyum sorunları gibi bireysel faktörlerin (Low ve Espelage, 2013) aracı rol oynadı̆̆ 1 bildirilmiştir. Ayrıca yakın zamanlı bir meta-analiz çalışmasında, ebeveyn sıcaklığının ergenin sosyal ve duygusal gelişimini destekleyici ve diğer ebeveyn izleme stratejilerinin etkisini arttırıcı oldukça önemli bir rolü olduğu ortaya konmuştur (Liu, Chen ve Brown, 2020). Bu bağlamda yürütülen çoğu araştırmada ya çocuk yetiştirmedeki etkin rolünden dolayı yalnızca anneye odaklanılmakta ya da mevcut çalışmada olduğu gibi anne ve babaya ilişkin değerlendirmeler birlikte ele alınmaktadır (Spriggs, Iannotti, Nansel ve Haynie, 2007). Oysaki ebeveynin cinsiyetini ele alan çalışmalarda her iki ebeveynin ergenle ilişkilerinin farklı olduğu, bu nedenle de anneden ve babadan algılanan ebeveynlik uygulamalarının ergenin farklı sonuç davranışlarıyla ilişkili olduğu vurgulanmaktadır (Laible ve Carlo, 2004). Dolayısıyla ileride yapılacak olan çalışmalarda ergenin davranışsal sorunları ve bireysel özellikleri ile ebeveyn-ergen ilişkilerinin daha kapsamlı olarak incelenmesinin gerekliliğine işaret edilmektedir (Baldry ve ark., 2019). Bu yaklaşım Bronfenbrenner'in (1999) insan gelişimini, aktif ve değişim içinde olan birey ile onun yakın ve uzak çevresi içinde yer alan diğer ajanlar arasındaki karşılıklı bir etkileşimin sonucu olarak ele aldığ 1 Biyoekolojik Modeline de uygun olacaktır. Bu araştırmada bu yaklaşıma uygun bir biçimde, yaşam doyumu, ergenin okul ve arkadaş çevresini de içerecek şekilde ölçülmüştür. Araştırmalar, hem okulda hem de sanal ortamda deneyimlenen zorbalığın akran algısı ve okul iklimi ile ilişkili olduğunu ortaya koymuş (Bayar ve Uçanok, 2012; Williams ve Guerra, 2007) ve her iki ortamda da zorbalığa dahil olan ergenlerin yarısından fazlasının aynı bireyler olduğu rapor edilmiştir (Burnukara ve Uçanok, 2012). Bu bulgularla paralel biçimde, bu araştırmada, ebeveyn izlemesi ile benlik, okul, arkadaşlar ve yaşanılan çevreyi içeren yaşam doyumu arasındaki ilişkiye siber zorbalığın aracılık etmesi, bilgi ve iletişim teknolojileri aracılığıyla gerçekleşen zorbalığın etkilerinin tek bir mekanla sınırlı kalmadığına işaret ediyor olabilir. 
Geçtiğimiz eğitim-öğretim döneminde, küresel ölçekte yaşanan salgın okul sistemini de değişime zorlayarak oldukça hızlı bir biçimde çevrimiçi uzaktan eğitime geçilmesini gerektirmiştir (Sun, Tang ve Zuo, 2020). Bu nedenle, önümüzdeki süreçte okul ikliminde, öğretmenlerin rolünde ve genel anlamda öğretim yöntemlerinde önemli bir değişim ve dönüşüm yaşanacağı öngörülebilir. Ayrıca mevcut koşullar nedeniyle, yoğun hatta aşırı kullanımdan dolayı çevrimiçi platformlar kaçınılmaz biçimde ergen sağlığını doğrudan etkileyen alanlar haline gelmiştir. Dolayısıyla bu araştırmadan elde edilen bulgulardan hareketle, sanal ortamı da içerecek şekilde ergenlerin akran ilişkilerini desteklemeye yönelik ebeveyn akran yönetimi stratejilerine odaklanılması işlevsel olabilir.

Araştırmanın bulguları sınırlılıkları çerçevesinde değerlendirilmelidir. Bu çalışma enlemesine kesitsel yöntemle yürütüldüğü için nedensel ilişkiler ortaya koyamadığı ve elde edilen ilişkilerin iki yönlü olarak değerlendirilmesinin mümkün olduğu unutulmamalıdır. Bu bağlamda, ebeveyn izlemesi, siber zorbalık ile ergenin yaşam doyumu arasındaki karşılıklı ilişkilerin boylamsal çalışmalarla ortaya konmasına ihtiyaç duyulmaktadır. Diğer bir sınırlılık ise yalnızca ergenden alınan öz bildirim türündeki raporlardır. Bu sebeple bundan sonra yapılacak olan çalışmalarda farklı kaynaklardan alınacak (anne-baba, öğretmen, akran raporu gibi) bilgiler hem sonuçların güvenirliğini arttırabilir hem de sosyal istenirlik problemini azaltmaya imkan verebilir. Ebeveyn izlemesi ölçeğine eklenen internet ortamına yönelik maddeler, siber zorbalık ile algılanan ebeveyn bilgisi ilişkisine dair elde edilen sonuçları güçlendirmiş olsa da, ileride yapılacak olan çalışmalarda, ebeveynin farklı türden izleme uygulamalarının da ele alınması önerilebilir.

Ergenliğe geçişle birlikte ebeveyn otoritesinin sorgulanmaya başlaması, özerk düşünme ve hareket etme eğiliminin artması ve ebeveyn gözetiminden uzakta akranlarla geçirilen sürenin artması (Smetana, 2017) gibi çok sayıda faktör ebeveyn kontrolünün farklı boyutları ile derinlemesine incelenmesi gerektiğine işaret etmektedir. Sonuç olarak, bu araştırmadan elde edilen bulgular da algılanan ebeveyn izlemesinin ergenlerin internet ortamında riskli davranışlarda bulunmasında koruyucu bir rolü olduğunu ve bireyin iyilik haline katkı sağladığını ortaya koymuştur. Örneklemin altı farklı ilden geniş bir katılımcı grubundan oluşması ise temsil ediciliği ve araştırma sonuçlarının genellenebilirliğini güçlendirmiştir. Bu bulgular, ergenlerde riskli davranışları azaltmada ve onların sağlıklı bireyler olarak yetişmelerinde aktif izleme uygulamalarının rolünü vurgulayan görüşleri desteklemektedir. 
Etik Kurul Onayı: Araştırma için Milli Eğitim Bakanlığı ve etik kurul izinleri alınmıştır.

Hakem Değerlendirmesi: Dış bağımsız.

Yazar Katkıları: Çalışma Konsepti/Tasarım- N.T., D.K.S., Z.U.; Veri Toplama- N.T., D.K.S., Z.U.; Veri Analizi/ Yorumlama- N.T., D.K.S., Z.U.; Yazı Taslağı- N.T., D.K.S., Z.U.; İçeriğgin Eleştirel İncelemesi- N.T., D.K.S., Z.U.; Son Onay ve Sorumluluk- N.T., D.K.S., Z.U.

Çıkar Çatışması: Yazarlar çıkar çatışması bildirmemiştir.

Finansal Destek: Bu çalışma TUBİTAK Sosyal ve Beşeri Bilimler Araştırma Projeleri (Proje No:108K424) kapsamında desteklenmiştir.

Ethics Committee Approval: Permissions from the Ministry of National Education and the ethics committee were obtained for the research.

Peer-review: Externally peer-reviewed.

Author Contributions: Conception/Design of Study- N.T., D.K.S., Z.U.; Data Acquisition- N.T., D.K.S., Z.U.; Data Analysis/Interpretation- N.T., D.K.S., Z.U.; Drafting Manuscript- N.T., D.K.S., Z.U.; Critical Revision of ManuscriptN.T., D.K.S., Z.U.; Final Approval and Accountability- N.T., D.K.S., Z.U.

Conflict of Interest: The authors have no conflict of interest to declare.

Grant Support: This study was supported within the scope of TUBITAK Social and Human Sciences Research Projects (Project No:108K424).

\section{Kaynakça/References}

Álvarez-García, D., Pérez, J. C. N., González, A. D. ve Pérez, C. R. (2015). Risk factors associated with cybervictimization in adolescence. International Journal of Clinical and Health Psychology, 15(3), 226-235. https://doi.org/10.1016/j.ijchp.2015.03.002

Arıcak, O. T. (2009). Psychiatric symptomatology as a predictor of cyberbullying among university students. Eurasian Journal of Educational Research, 34, 167-184.

Arsenio, W. F., Adams, E. ve Gold, J. (2009). Social information processing, moral reasoning, and emotion attributions: Relations with adolescents' reactive and proactive aggression. Child Development, 80(6), 1739-1755. https://doi.org/10.1111/j.1467-8624.2009.01365.x

Baldry, A. C., Sorrentino, A. ve Farrington, D. P. (2019). Cyberbullying and cybervictimization versus parental supervision, monitoring and control of adolescents' online activities. Children and Youth Services Review, 96, 302-307. https://doi.org/10.1016/j.childyouth.2018.11.058

Barber, B. K. (1996). Parental psychological control: Revisiting a neglected construct. Child development, 67(6), 3296-3319. https://doi.org/.1111/j.1467-8624.1996.tb01915.x

Barber, B. K., Stolz, H. E. ve Olsen, J. A. (2005). Parental support, psychological control, and behavioral control: Assessing relevance across time, culture, and method: IV. Assessing relevance across time: U.S. analyses and results. Monographs of the Society for Research in Child Development, 70(4), 26-57. https://doi.org/10.1111/j.1540-5834.2005.00368.x

Bartolo, M. G., Palermiti, A. L., Servidio, R. ve Musso, P. (2019). Mediating processes in the relations of parental monitoring and school climate with cyberbullying: The role of moral disengagement. Europe's Journal of Psychology, 15(3), 568-594. https://doi.org/10.5964/ejop. v15i3.1742

Bayar, Y. ve Uçanok, Z. (2012). Okul sosyal iklimi ile geleneksel ve sanal zorbalık arasındaki ilişkiler: Genellenmiş akran algısının aracı rolü. Türk Psikoloji Dergisi, 70, 101- 114. https://doi. org/10.31828/tpd1300443320120000m000077

Bolger, K. E. ve Patterson, C. J. (2001). Developmental pathways from child maltreatment to peer rejection. Child Development, 72(2), 549-568. https://doi.org/10.1111/1467-8624.00296 
Boniel-Nissim, M., Tabak, I., Mazur, J., Borraccino, A., Brooks, F., Gommans, R. ... ve Finne, E. (2015). Supportive communication with parents moderates the negative effects of electronic media use on life satisfaction during adolescence. International Journal of Public Health, 60(2), 189-198. https://doi.org/10.1007/s00038-014-0636-9

Bowler, L., Knobel, C. ve Mattern, E. (2015). From cyberbullying to well-being: A narrative-based participatory approach to values-oriented design for social media. Journal of the Association for Information Science and Technology, 66(6), 1274-1293. https://doi.org/10.1002/asi.23270

Bronfenbrenner, U. (1999). Environments in developmental perspective: Theoretical and operational models. S. L. Friedman ve T. D. Wachs (Ed.), Measuring environment across the life span: Emerging methods and concepts içinde (s. 3-28). American Psychological Association. https://doi. org/10.1037/10317-001

Burnukara, P. (2009). İlk ve orta ergenlikte geleneksel ve sanal akran zorbalı̆̆ına ilişkin betimsel bir inceleme (Yayınlanmamış yüksek lisans tezi). Hacettepe Üniversitesi, Ankara.

Burnukara, P. ve Uçanok, Z. (2012). Okul ortamı ve sanal ortamda meydana gelen akran zorbalığı ne ölçüde örtüşüyor? Türk Psikoloji Dergisi, 27(69), 81-100. https://doi.org/10.31828/ tpd1300443320120000m000084

Card, N. A., Stucky, B. D., Sawalani, G. M. ve Little, T. D. (2008). Direct and indirect aggression during childhood and adolescence: A meta-analytic review of gender differences, intercorrelations, and relations to maladjustment. Child Development, 79(5), 1185-1229. https://doi.org/10.1111/ j.1467-8624.2008.01184.x

Caspi, A. ve Gorsky, P. (2006). Online deception: Prevalence, motivation, and emotion. CyberPsychology \& Behavior, 9(1), 54-59. https://doi.org/10.1089/cpb.2006.9.54

Chang, F. C., Chiu, C. H., Miao, N. F., Chen, P. H., Lee, C. M., Chiang, J. T. ve Pan, Y. C. (2015). The relationship between parental mediation and Internet addiction among adolescents, and the association with cyberbullying and depression. Comprehensive Psychiatry, 57, 21-28. https://doi. org/10.1016/j.comppsych.2014.11.013

Darling, N. ve Steinberg, L. (1993). Parenting style as context: An integrative model. Psychological Bulletin, 113(3), 487-496. https://doi.org/10.1037/0033-2909.113.3.487

Diener, E., Suh, E. M., Lucas, R. E. ve Smith, H. L. (1999). Subjective well-being: Three decades of progress. Psychological Bulletin, 125(2), 276. https://doi.org/10.1037/0033-2909.125.2.276

Duy, B. ve Yildız, M. A. (2020). Investigation of the psychometric properties of the Turkish adaptation of positivity scale for adolescents and young adults. Psikoloji Çalışmaları, 40(1), 1-18. https://doi. org/10.26650/SP2018-0017

Elsaesser, C., Russell, B., Ohannessian, C. M. ve Patton, D. (2017). Parenting in a digital age: A review of parents' role in preventing adolescent cyberbullying. Aggression and Violent Behavior, 35, 6272. https://doi.org/10.1016/j.avb.2017.06.004

Erdur-Baker, Ö. ve Kavşut, F. (2007). Akran zorbalığının yeni yüzü: Siber zorbalık. Eurasian Journal of Educational Research, 27, 31-42.

Espelage, D. L., Bosworth, K. ve Simon, T. R. (2001). Short-term stability and prospective correlates of bullying in middle-school students: An examination of potential demographic, psychosocial, and environmental influences. Violence and Victims, 16(4), 411-426. https://doi.org/10.1891/08866708.16.4.411

Finnegan, R. A., Hodges, E. V. E. ve Perry, D. G. (1998). Victimization by peers: Associations with children's reports of mother-child interaction. Journal of Personality and Social Psychology, 75, 1076-1086. https://doi.org/10.1037/0022-3514.75.4.1076 
Flaspohler, P. D., Elfstrom, J. L., Vanderzee, K. L., Sink, H. E. ve Birchmeier, Z. (2009). Stand by me: The effects of peer and teacher support in mitigating the impact of bullying on quality of life. Psychology in the Schools, 46(7), 636-649. https://doi.org/10.1002/pits.20404

Floros, G. D., Siomos, K. E., Fisoun, V., Dafouli, E. ve Geroukalis, D. (2013). Adolescent online cyberbullying in Greece: The impact of parental online security practices, bonding, and online impulsiveness. Journal of School Health, 83(6), 445-453. https://doi.org/10.1111/josh.12049

Galambos, N. L., Barker, E. T. ve Almeida, D. M. (2003). Parents do matter: Trajectories of change in externalizing and internalizing problems in early adolescence. Child Development, 74(2), 578-594. https://doi.org/10.1111/1467-8624.7402017

Hau, K. T. ve Marsh, H. W. (2004). The use of item parcels in structural equation modelling: Non-normal data and small sample sizes. British Journal of Mathematical and Statistical Psychology, 57(2), 327-351. https://doi.org/10.1111/j.2044-8317.2004.tb00142.x

Hawk, S. T., Hale, W. W., Raaijmakers, Q. A. W. ve Meeus, W. (2008). Adolescents'perceptions of privacy invasion in reaction to parental solicitation and control. The Journal of Early Adolescence, 28(4), 583-608. https://doi.org/10.1177/0272431608317611

Hemphill, S. A. ve Heerde, J. A. (2014). Adolescent predictors of young adult cyberbullying perpetration and victimization among Australian youth. Journal of Adolescent Health, 55(4), 580-587. https:// doi.org/10.1016/j.jadohealth.2014.04.014

Hilooğlu, S. (2009). İlköğretim ikinci kademe öğrencilerinin zorbaca davranışlarını yordamada sosyal beceri ve yaşam doyumunun rolü (Yayınlanmamış yüksek lisans tezi). Çukurova Üniversitesi, Adana.

Hong, J. S. ve Espelage, D. L. (2012). A review of research on bullying and peer victimization in school: An ecological system analysis. Aggression and Violent Behavior, 17(4), 311-322. https:// doi.org/10.1016/j.avb.2012.03.003

Hong, J. S., Lee, J., Espelage, D. L., Hunter, S. C., Patton, D. U. ve Rivers Jr, T. (2016). Understanding the correlates of face-to-face and cyberbullying victimization among US adolescents: A socialecological analysis. Violence and Victims, 31(4), 638-663. https://doi.org/10.1891/0886-6708.VVD-15-00014

Hoskins, D. H. (2014). Consequences of parenting on adolescent outcomes. Societies, 4(3), 506-531. https://doi.org/10.3390/soc4030506

Hu, L. ve Bentler, P. M. (1999). Cutoff criteria for fit indexes in covariance structure analysis: Conventional criteria versus new alternatives. Structural Equation Modeling, 6(1), 1-55. https:// doi.org/10.1080/10705519909540118

Huebner, E. S. (1994). Preliminary development and validation of a multidimensional life satisfaction scale for children. Psychological Assessment, 6(2), 149-158. https://doi.org/10.1037/10403590.6.2.149

Huebner, E. S. (2004). Research on assessment of life satisfaction of children and adolescents. Social Indicators Research, 66(1-2), 3-33. https://doi.org/10.1023/B:SOCI.0000007497.57754.e3

Irmak, S. ve Kuruüzüm, A. (2008). Turkish validity examination of The Multidimensional Students' Life Satisfaction Scale. Social Indicators Research, 92, 13-23. https://doi.org/10.1007/s11205-0089284-x

Jacobson, K. C. ve Crockett, L. J. (2000). Parental monitoring and adolescent adjustment: An ecological perspective. Journal of Research on Adolescence, 10(1), 65-97. https://doi.org/10.1207/ SJRA1001_4

Jöreskog, K. G. ve Sörbom, D. (1999). LISREL 8. Chicago: Scientific Software International. 
Juvonen, J. ve Gross, E. F. (2008). Extending the school grounds?-Bullying experiences in cyberspace. Journal of School Health, 78(9), 496-505. https://doi.org/10.1111/j.1746-1561.2008.00335.x

Kakihara, F., Tilton-Weaver, L., Kerr, M. ve Stattin, H. (2010). The relationship of parental control to youth adjustment: Do youths' feelings about their parents play a role? Journal of Youth and Adolescence, 39(12), 1442-1456. https://doi.org/10.1007/s10964-009-9479-8

Karlıer-Soydaş, D. ve Uçanok, Z. (2014). Ergenlerin bilgi ve iletişim teknolojilerini kullanım özellikleri sanal ortamda zorbalığa dahil olmayı açıklıyor mu? Çocuk ve Gençlik Ruh Sağlı̆̆ı Dergisi, 21(1), $17-32$

Kerr, M. ve Stattin, H. (2000). What parents know, how they know it, and several forms of adolescent adjustment: Further support for a interpretation of monitoring. Developmental Psychology, 36(3), 366-380. https://doi.org/10.1037/0012-1649.36.3.366

Knoester, C., Haynie, D. L. ve Stephens, C. M. (2006). Parenting practices and adolescents' friendship networks. Journal of Marriage and Family, 68, 1247-1260. https://doi.org/10.1111/j.17413737.2006.00326.x

Kowalski, R. M., Giumetti, G. W., Schroeder, A. N. ve Lattanner, M. R. (2014). Bullying in the digital age: A critical review and meta-analysis of cyberbullying research among youth. Psychological Bulletin, 140(4), 1073. https://doi.org/10.1037/a0035618

Kumpulainen, K., Räsänen, E. ve Puura, K. (2001). Psychiatric disorders and the use of mental health services among children involved in bullying. Aggressive Behavior: Official Journal of the International Society for Research on Aggression, 27(2), 102-110. https://doi.org/10.1002/ab.3

Laible, D. J. ve Carlo, G. (2004). The differential relations of maternal and paternal support and control to adolescent social competence, self-worth, and sympathy. Journal of Adolescent Research, 19(6), 759-782. https://doi.org/10.1177/0743558403260094

Laird, R. D., Zeringue, M. M. ve Lambert, E. S. (2018). Negative reactions to monitoring: Do they undermine the ability of monitoring to protect adolescents? Journal of Adolescence, 63, 75-84. https://doi.org/10.1016/j.adolescence.2017.12.007

Larson, R. W., Richards, M. H., Moneta, G., Holmbeck, G. ve Duckett, E. (1996). Changes in adolescents' daily interactions with their families from ages 10 to 18: Disengagement and transformation. Developmental Psychology, 32(4), 744-754. https://doi.org/10.1037/00121649.32.4.744

Lereya, S. T., Samara, M. ve Wolke, D. (2013). Parenting behavior and the risk of becoming a victim and a bully/victim: A meta-analysis study. Child Abuse \& Neglect, 37(12), 1091-1108. https://doi. org/10.1016/j.chiabu.2013.03.001

Liu, D., Chen, D. ve Brown, B. B. (2020). Do parenting practices and child disclosure predict parental knowledge? A meta-analysis. Journal of Youth and Adolescence, 49(1), 1-16. https://doi. org/10.1007/s10964-019-01154-4

Livingstone, S. ve Bober, M. (2004). UK children go online: surveying the experiences of young people and their parents [online]. London: LSE Research Online. Erişim: 7 Mayıs 2020, http://eprints.lse. ac.uk/395/

Livingstone, S. ve Helsper, E. (2007). Taking risks when communicating on the internet: The role of offline social-psychological factors in young people's vulnerability to online risks. Information, Communication and Society, 10(5), 619-643. https://doi.org/10.1080/13691180701657998

Low, S. ve Espelage, D. (2013). Differentiating cyber bullying perpetration from non-physical bullying: Commonalities across race, individual, and family predictors. Psychology of Violence, 3(1), 39-52. https://doi.org/10.1037/a0030308 
Lyubomirsky, S., King, L. ve Diener, E. (2005). The benefits of frequent positive affect: Does happiness lead to success? Psychological Bulletin, 131(6), 803-855. https://doi.org/10.1037/00332909.131.6.803

Meter, D. J. ve Bauman, S. (2018). Moral disengagement about cyberbullying and parental monitoring: Effects on traditional bullying and victimization via cyberbullying involvement. Journal of Early Adolescence, 38(3), 303-326. https://doi.org/10.1177/0272431616670752

Mitchell, K. J., Wolak, J. ve Finkelhor, D. (2008). Are blogs putting youth at risk for online sexual solicitation or harassment? Child Abuse \& Neglect, 32(2), 277-294. https://doi.org/10.1016/j. chiabu.2007.04.015

Moore, P. M., Huebner, E. S. ve Hills, K. J. (2012). Electronic bullying and victimization and life satisfaction in middle school students. Social Indicators Research, 107(3), 429-447. https://doi. org/10.1007/s11205-011-9856-Z

Morrison, G. M., Robertson, L., Laurie, B. ve Kelly, J. (2002). Protective factors related to antisocial behavior trajectories. Journal of Clinical Psychology, 58, 277-290. https://doi.org/10.1002/ jclp. 10022

Myers, D. G. ve Diener, E. (1995). Who is happy? Psychological Science, 6(1), 10-19. https://doi. org/10.1111/j.1467-9280.1995.tb00298.x

Navarro, R., Ruiz-Oliva, R., Larrañaga, E. ve Yubero, S. (2015). The impact of cyberbullying and social bullying on optimism, global and school-related happiness and life satisfaction among 10-12-yearold schoolchildren. Applied Research in Quality of Life, 10, 15-36. https://doi.org/10.1007/s11482013-9292-0

Navarro, R., Serna, C., Martínez, V. ve Ruiz-Oliva, R. (2013). The role of Internet use and parental mediation on cyberbullying victimization among Spanish children from rural public schools. European Journal of Psychology of Education, 28(3), 725-745. https://doi.org/10.1007/ s10212-012-0137-2

Nocentini, A., Fiorentine, G., Di Paola, L. ve Menesini, E. (2018). Parents, family characteristics and bullying behavior: A systematic review. Aggression and Violent Behavior, 45, 41-50. https://doi. org/10.1016/j.avb.2018.07.010

Noom, M. J., Deković, M. ve Meeus, W. H. (1999). Autonomy, attachment and psychosocial adjustment during adolescence: A double-edged sword? Journal of Adolescence, 22(6), 771-783. https://doi. org/10.1006/jado.1999.0269

Olweus, D. (2013). School bullying: Development and some important challenges. Annual Review of Clinical Psychology, 9, 751-780. https://doi.org/10.1146/annurev-clinpsy-050212-185516

Palfrey J. ve Gasser, U. (2008). Born digital: Understanding the first generation of digital natives. Basic Civitas Books: New York.

Patterson, G. R. ve Stouthamer-Loeber, M. (1984). The correlation of family management practices and delinquency. Child Development, 55(4) 1299-1307. https://doi.org/10.2307/1129999

Perren, S., Gutzwiller-Helfenfinger, E., Malti, T. ve Hymel, S. (2012). Moral reasoning and emotion attributions of adolescent bullies, victims, and bully-victims. British Journal of Developmental Psychology, 30(4), 511-530. https://doi.org/10.1111/j.2044-835X.2011.02059.x

Pettit, G. S., Laird, R. D., Dodge, K. A., Bates, J. E. ve Criss, M. M. (2001). Antecedents and behaviourproblem outcomes of parental monitoring and psychological control in early adolescence. Child Development, 72(2), 583-598. https://doi.org/10.1111/1467-8624.00298

Piko, B. F. ve Hamvai, C. (2010). Parent, school and peer-related correlates of adolescents' life satisfaction. Children and Youth Services Review, 32(10), 1479-1482. https://doi.org/10.1016/j. childyouth.2010.07.007 
Raskauskas, J. ve Stoltz, A. D. (2007). Involvement in traditional and electronic bullying among adolescents. Developmental Psychology, 43, 564-575. https://doi.org/10.1037/0012-1649.43.3.564

Sasson, H. ve Mesch, G. (2014). Parental mediation, peer norms and risky online behavior among adolescents. Computers in Human Behavior, 33, 32-38. https://doi.org/10.1016/j.chb.2013.12.025

Satorra, A. ve Bentler, P. M. (1994). Corrections to test statistics and standard errors in covariance structure analysis. A. von Eye ve C. C. Clogg (Ed.), Latent variables analysis: Applications for developmental research içinde (s. 399-419). Newbury Park, CA: Sage.

Sayıl, M., Kındap, Y., Bayar, Y., Bayraktar, F., Kurt, D. Tığrak, A. ve Yaban, H. (2012). Ergenlik döneminde ebeveynlik ve ergenin psikososyal uyumu. Ankara: Hacettepe Üniversitesi Yayınları.

Schiffrin, H. H., Liss, M., Miles-McLean, H., Geary, H. A., Erchull, A. J. ve Tashner, T. (2014). Helping or hovering? The effects of helicopter parenting on college students' well-being. Journal of Child and Family Studies, 23(3), 548-557. https://doi.org/10.1007/s10826-013-9716-3

Shapka, J. D. ve Law, D. M. (2013). Does one size fit all? Ethnic differences in parenting behaviors and motivations for adolescent engagement in cyberbullying. Journal of Youth and Adolescence, 42(5), 723-738. https://doi.org/10.1007/s10964-013-9928-2

Smetana, J. G. (1997). Parenting and the development of social knowledge reconceptualized: A social domain analysis. J. E. Grusec ve L. Kuczynski (Ed.), Parenting and children's internalization of values: A handbook of contemporary theory içinde (s. 162-192). John Wiley \& Sons Inc.

Smetana, J. G. (2017). Current research on parenting styles, dimensions, and beliefs. Current Opinion in Psychology, 15, 19-25. https://doi.org/10.1016/j.copsyc.2017.02.012

Smith, P. K., Mahdavi, J., Carvalho, M., Fisher, S., Russell, S. ve Tippett, N. (2008). Cyberbullying, its nature and impact in secondary school pupils. The Journal of Child Psychology and Psychiatry, 49, 376-385. https://doi.org/10.1111/j.1469-7610.2007.01846.x

Sobel, M. E. (1982). Asymptotic confidence intervals for indirect effects in structural equation models. S. Leinhardt (Ed.), Sociological methodology içinde (s. 290-312). Washington, DC: American Sociological Association. https://doi.org/10.2307/270723

Spriggs, A. L., Iannotti, R. J., Nansel, T. R. ve Haynie, D. L. (2007). Adolescent bullying involvement and perceived family, peer and school relations: Commonalities and differences across race/ethnicity. Journal of Adolescent Health, 41(3), 283-293. https://doi.org/10.1016/j.jadohealth.2007.04.009

Stattin, H. ve Kerr, M. (2000). Parental monitoring: A reinterpretation. Child Development, 71(4), 1072-1085. https://doi.org/10.1111/1467-8624.00210

Steinberg, L. ve Silk, J. S. (2002). Parenting adolescents. M. H. Bornstein (Ed.), Handbook of parenting: Children and parenting içinde (s. 103-133). Lawrence Erlbaum Associates Publishers. https://doi. org/10.4324/9780429440847

Suldo, S. M. ve Huebner, E. S. (2004). The role of life satisfaction in the relationship between authoritative parenting dimensions and adolescent problem behavior. Social Indicators Research, 66(1-2), 165195. https://doi.org/10.1023/B:SOCI.0000007498.62080.1e

Sun, L., Tang, Y. ve Zuo, W. (2020). Coronavirus pushes education online. Nature Materials, 19(6), 687-687. https://doi.org/10.1038/s41563-020-0678-8

Topçu, Ç. (2008). The relationship of cyberbullying to empathy, gender, traditional bullying, internet use and adult monitoring (Yayınlanmamış yüksek lisans tezi). Orta Doğu Teknik Üniversitesi, Ankara.

Topçu, Ç., Erdur-Baker, Ö. ve Çapa-Aydın Y. (2008). Examination of cyberbullying experiences among Turkish students from different school types. Cyberpsychology \& Behavior, 11(6), 643-648. https:// doi.org/10.1089/cpb.2007.0161 
Türkiye İstatistik Kurumu [TÜIK] (2019). Bilgi Toplumu İstatistikleri, 2004-2019. Erişim: 13 Mayıs 2020, TÜİK Ağ Sayfası: http://tuik.gov.tr/UstMenu.do?metod=temelist

Türkileri İnselöz, N. ve Uçanok, Z. (2013). Ergenlerde sanal zorbalik: Nedenler, duygular ve baş etme yollarinin niteliksel analizi. Türk Psikoloji Yazilari, 16(32), 20-44. https://doi.org/ 10.31828/ tpy1301996120130000m000086

Valois, R. F., Kerr, J. C. ve Huebner, S. E. (2012) Peer victimization and perceived life satisfaction among early adolescents in the United States. American Journal of Health Education, 43(5), 258 268. https://doi.org/10.1080/19325037.2012.10599244

Wachs, S. (2012). Moral disengagement and emotional and social difficulties in bullying and cyberbullying: Differences by participant role. Emotional and Behavioural Difficulties, 17(3-4), 347-360. https://doi.org/10.1080/13632752.2012.704318

White, F. A. (1996). Parent-adolescent communication and adolescent decision-making. Journal of Family Studies, 2(1), 41-56. https://doi.org/10.5172/jfs.2.1.41

White, F. A. ve Matawie, K. M. (2004). Parental morality and family processes as predictors of adolescent morality. Journal of Child and Family Studies, 13(2), 219-233. https://doi.org/10.1023/ B:JCFS.0000015709.81116.ce

Williams, K. ve Guerra, N. G. (2007). Prevalence and predictors of internet bullying. Journal of Adolescent Health, 41, 14-21. https://doi.org/10.1016/j.jadohealth.2007.08.018

Wolak, J., Mitchell, K. J. ve Finkelhor, D. (2007). Does online harassment constitute bullying? An exploration of online harassment by known peers and online-only contacts. Journal of Adolescent Health, 41(6), 51-58. https://doi.org/10.1016/j.jadohealth.2007.08.019

Wright, M. F. (2017). Adolescents' perceptions of popularity-motivated behaviors, characteristics, and relationships in cyberspace and cyber aggression: The role of gender. Cyberpsychology, Behavior and Social Networking, 20(6), 355-361. https://doi.org/10.1089/cyber.2016.0693

Ybarra, M. L. (2004). Linkages between depressive symptomatology and internet harassment among young regular internet users. CyberPsychology \& Behavior, 7(2), 247-257. https://doi. org $/ 10.1089 / 109493104323024500$

Ybarra, M. L. ve Mitchell, K. J. (2004). Online aggressor/targets, aggressors and targets: A comparison of associated youth characteristics. Journal of Child Psychology and Psychiatry, 45(7), 1308-1316. https://doi.org/10.1111/j.1469-7610.2004.00328.x

Ybarra, M. L., Mitchell, K. J., Wolak, J. ve Finkelhor, D. (2006). Examining characteristics and associated distress related to internet harassment: Findings from the second youth Internet safety survey. Pediatrics, 118(4), e1169-e1177. https://doi.org/10.1542/peds.2006-0815

You, S., Furlong, M. J., Felix, E., Sharkey, J. D., Tanigawa, D. ve Green, J. G. (2008). Relations among school connectedness, hope, life satisfaction, and bully victimization. Psychology in the Schools, 45(5), 446-460. https://doi.org/10.1002/pits.20308 
